\title{
A Unique Adaptive Neuro Fuzzy Inference System for Optimum Decision Making Process in a Natural Gas Transmission Unit
}

\author{
A. Azadeh ${ }^{\text {a }}$ Z. Gaeini ${ }^{\text {a }}$, S. Motevali Haghighi ${ }^{\text {a\&b }}$, B. Nasirian ${ }^{\text {a }}$ \\ ${ }^{a}$ School of Industrial and Systems Engineering, Centre of Excellence for Intelligent-Based Experimental Mechanics, \\ and Department of Engineering Optimization Research, College of Engineering, University of Tehran, Iran \\ ${ }^{b}$ Department of Industrial Engineering, Esfarayen University of Technology, Esfarayen, 9661998195, Iran
}

\begin{abstract}
In this study, a unique adaptive neuro fuzzy inference system for optimization of decision making process in natural gas transmission unit is presented. To do this, macro-ergonomics and integrated resilience engineering factors are considered as outputs to assess operators' performance and decision styles. Evaluation of decision-making styles of control room operators would help managers adjust job specification with human characteristics. In this regard, a pertinent standard questionnaire is designed to collect required data. Operators' decision styles are identified by standard questionnaire and, then, their efficiency values are calculated by considering macro-ergonomics factors through a unique adaptive neuro-fuzzy inference system (ANFIS). Moreover, fuzzy data envelopment analysis (FDEA) model is applied to validate the obtained results. Analysis of variance is used to investigate the results of ANFIS. The results show that the best decision style is flexible DM style wherein information is pertinently used as needed and there are multiple focuses for making decisions. In addition, the results reveal that information flow, safety, system efficiency, redesign, preparedness, and learning have the lowest efficiency values amongst macro-ergonomics and integrated resilience engineering factors and require more attention. Then, DM speed and violation of regulations obtain the best results in the gas transmission unit. This is the first study that introduces a unique intelligent adaptive
\end{abstract}


framework to assess and optimize decision making process in a gas transmission unit in context of macro-ergonomics and integrated resilience engineering factors.

Keywords: Decision Making Process; Decision Styles; Macro-Ergonomics; Integrated Resilience Engineering; Adaptive Neuro-Fuzzy Inference System (ANFIS); Fuzzy Data Envelopment Analysis (FDEA)

\section{Introduction}

Human factors are still the major cause of accidents in process industries despite advances in this area and replacement of operators with machines. Decision-making (DM) process is an important module in each stage of a gas transmission unit. People make their decisions in different ways. Awareness of these differences is useful for desirably communicating with others such as co-workers and supervisors. DM styles refer to learned habits for making decisions. In order to have an efficient performance in our job, we need to know about our decision style. Furthermore, it is required to learn how to recognize others' decision styles and match decision styles with suitable job positions (Driver, 1991). Driver decision styles are decisive, flexible, hierarchic, integrative and systematic. Moreover, all individuals have one main decision style which can be defined and retrieved by Driver decision style exercise (DDSE) (Driver et al., 1998).

Operators make decisions as parts of a system or an organization. Hence, connections with other parts of a system should be considered in order to optimize human performance. Technology of human, organization, environment and machine is defined as macro-ergonomics (Hendrick, 1995). Macro-ergonomics approach concurrently optimizes human, machine, environment, management, and organization performance. A system is efficient when its 
subsystems are designed properly (Pasmore, 1988). Decision making styles refer to learned habits for making decisions. In order to have an efficient performance in jobs, managers need to know about their staff's decision style. Driver (1998) introduced decision styles containing five styles, namely decisive, flexible, hierarchic, integrative, and systemic ones. The evaluation and identification of decision styles may be quite beneficial in several areas. For example, Galotti et al. (2006) studied decision styles in real life situations. The authors analyzed decision styles among 1033 students in the United States. Dewberry et al. (2013) conducted a study to explore the association between DM eligibility in everyday life and DM styles. Wood and Highhouse (2014) examined the relationship between decision styles and making high-quality decisions. Curşeu and Schruijer (2012) investigated the relationship between the five DM styles and evaluated rationality in DM among 102 middle-level managers. Scott and Bruse (1995) proved that there is no significant relationship between decision styles and performance factors in the process of selecting a major. Similarly, Baiocco et al. (2009) evaluated the relationship between students' decision styles and achievement factors among 700 students. They found that the students with rational style are more successful in comparison with the students with spontaneous style. In the same way, the students with spontaneous style skip class more than other students. The results of another study, aimed at discovering the relationships between perfectionism and DM style, showed that dependent and rational styles have higher predicative power of career exploration (Öngen, 2014). Fox and Spence (1999) analyzed managerial decision styles of technological projects. They found that managers tend to be more analytical and cautious about behavioral styles. They proved that managers prefer to change their styles into integrated styles in complex situations. Ergonomic DM patterns with respect to healthcare were studied in the United States by Piegorsch et al. (2006). Moreover, Amazt and Idris (2011) 
conducted a study on managers' decision styles and analyzed the impact of decision styles on staff satisfaction. They found no significant relationship between the stated factors. In addition, Jamian et al. (2013) studied decision styles among the officials of 4 universities and concluded that the integrative style could be the best style for managers.

Human error is still a major cause of failure in process plants, particularly in gas refineries which can result in failure of accomplishment a particular task (Gandhi, 2011). Thus, human element, as an important part of a system, should be further considered and improved concurrently with technological, environmental, and organizational aspects of a system. This study presents an integrated macro-ergonomics approach to identify optimum decision styles for all job positions in an actual gas transmission unit though a unique approach. Moreover, efficiency of each operator is calculated by adaptive neuro-fuzzy inference system (ANFIS) algorithm which is based on macro-ergonomics indicators. This will consequently identify the best decision style for each position. This is the first study that introduces an integrated approach in order to optimize the performance of gas transmission unit by considering macro-ergonomics and integrated resilience engineering factors and human decision styles. In this study, decision styles are analyzed in the context of macro-ergonomics and resilience engineering. In recent decades, macro-ergonomics has caught the attention of researchers and macro-ergonomics factors have been assessed in several industrial environments. Azadeh et al. (2008) presented an integrated multivariate model to analyze macro-ergonomics indicators in a natural gas plant. Azadeh et al. (2011) proposed a neural network (NN) algorithm to assess and optimize the HSE management systems and job satisfaction in a gas refinery. Morel et al. (2009) analyzed macroergonomics and resilience factors for a professional fishing case which is a dangerous process for human. An intelligent algorithm with the aim of recognizing the optimum combination of 
demographic variables for HSEE-ISO systems was presented in a process plant by means of artificial neural network (ANN) and ANFIS (Azadeh et al. 2013a). Moreover, other studies have focused on HSE, ergonomics, safety characteristics and job stress (Asadzadeh et al., 2013; Azadeh et al, 2013; Azadeh et al., 2014; Khandan et al., 2012) through fuzzy cognitive map, continuous improvement cycle and fuzzy data envelopment analysis. From among the other studies in this area, one can refer to the evaluation of macro-ergonomics in health care facility by Hallock et al. (2006); impact of macro-ergonomics in production systems by Luczak (1995); and promoting economics in total quality management by Lee (2005). The importance of decision making process in natural gas processes has been discussed in several studies. In this regard, Tang et al. (2015) proposed a maintenance decision making framework by using analytic hierarchy process (AHP) and Monte Carlo simulation. Michelsen et al. (2010) presented a framework to optimize and control natural gas processes. Deveci et al. (2015) applied a fuzzy based framework to select the best location for natural gas storage. To do this, they used fuzzy technique for order of preference by similarity to ideal solution (TOPSIS), elimination and choice expressing reality I (ELECTRE I).

Resilience engineering (RE) is a new concept for controlling and limiting accidents. The RE factors are including management commitment, preparedness, reporting culture, learning culture, awareness, and flexibility (Wreathall, 2006). Azadeh et al. (2014) introduced integrated resilience engineering and added four factors to aforementioned RE factors including fault tolerance, redundancy, team working, and self-organization. In this study, integrated resilience engineering and macro-ergonomics factors are took into account to evaluate decision making units. 
Although most of the above-mentioned studies have been performed in the context of macro-ergonomics and integrated resilience engineering factors, none of them have tackled the integration of decision styles, resilience engineering, and macro-ergonomics. This is the first study that integrates macro-ergonomics and integrated resilience engineering factors and DM process for the identification of optimum styles of operators in a real gas transmission unit. Moreover, the impact of DM styles on safety issues in gas transmission units has not been considered so far. Therefore, this is the first study that attempts to evaluate DM styles in the context of macro-ergonomics factor through an adaptive neuro-fuzzy algorithm. Moreover, the algorithm of this study is validated by a real gas transmission unit in Iran. Standard questionnaires are used to collect data from control room operators of the gas transmission unit. Then, a unique ANFIS is developed and used to identify optimum decision styles.

\section{Methodology}

This study is an attempt to identify the optimized decision styles for job positions in an actual gas transmission unit. To this end, it is necessary to find operators' decision styles according to Driver questionnaire in the first step. Next, the approach will find the best styles for each position according to macro-ergonomics and integrated resilience engineering factors. In this paper, macro-ergonomics factors are presented according to recent research findings (Azadeh et al., 2008; Azadeh et al., 2011; Hendrick and Kleiner, 1999; Hendrick, 2005). Thus, macro-ergonomics factors are as follows: (1) information flow; (2) communication with managers; (3) rules and procedures; (4) safety; (5) violation of regulation; (6) DM speed and control ability; (7) work pressure and stress; (8) system's efficiency; (9) redesign; (10) physical problems. Moreover, the integrated resilience engineering factors are as follows: (1) management commitment; (2) reporting culture; (3) learning; (4) awareness; (5) preparedness; 
(6) redundancy; (7) fault tolerance; (8) teamwork; (9) flexibility; (10) self-organization. The objective of this study is to propose an adaptive intelligent approach to calculate and enhance operators' performance considering macro-ergonomics and integrated resilience engineering factors. In addition, the best decision styles for each job position are recognized. This process is applied to an actual case in a gas transmission unit to appraise the application of this algorithm. Operators' efficiency values are measured by ANFIS tool with demographic factors namely age and education as inputs and macro-ergonomics and integrated resilience engineering factors as outputs. The required data are collected by standard decision styles and macro-ergonomics questionnaires. Thereafter, operators are ranked with efficiency values based on macroergonomics factors. Finally, optimized styles are obtained for the above-mentioned unit through ANFIS. The intelligent approach of this study helps managers reduce risk of accidents and increase total efficiency.

Two input groups (age and education) and 20 output groups (macro-ergonomics and integrated resilience engineering factors) are defined by designing and using a standard questionnaire. Age is defined in six groups; 1: under 18, 2: between 18 and 25, 3: between 25 and 35, 4: between 35 and 45, 5: between 45 and 55, and 6: over 55 years. Education is defined in 4 groups; 1: high school diploma, 2: associate degree, 3: bachelor, and 4: master and above. Then, the decision styles of 150 operators are obtained and their opinions about macroergonomics are analyzed by ANFIS. Moreover, the operators with specific decision styles are ranked with respect to macro-ergonomics factors and efficiency score obtained from ANFIS model. Aforementioned efficiency scores are calculated considering the ratio of the observed to predicted values for each output of decision making unit. The proposed approach can be achieved by applying eight main steps as follows: 


\section{Step 1: Information Gathering}

The operators from different shifts at the control room answered the questionnaire (presented in Appendix II) with a variety of items pertaining to macro-ergonomics in Iranian natural gas transmission units. The questionnaire consisted of 80 questions. Scoring of each question ranged from 1 to 10 . The questionnaire also extracted the basic demographic information of operators. Standard items of the questionnaire were adopted from reliable resources (Azadeh et al., 2011; Cooper and Schindler, 2003; Woodson, 1992; Kjellén, 2000). It should be noted that the raw data are presented in Appendix III.

\section{Step 2: Reliability of Questionnaire}

In order to ensure the reliability of the questionnaire, Cronbach's Alpha is applied.

\section{Step 3: Determination of Decision Styles}

DM styles are determined based on Driver standard questionnaire, DDSE (Driver Decision Style Exercise) whose validity and reliability have been confirmed during the last 15 years.

\section{Step 4: Data Preparation for ANFIS}

- Define and select the proper input and output variables

- $\quad$ Gather accessible data, set (S) including inputs and outputs for operators.

- Select the training data (S1) and validation data (S2) by dividing S into two subsets;

It should be noted that there must be a balance between the size of train and validation data sets. The validation data selection can be performed using a simple random choice when there are large amounts of accessible data 


\section{Step 5: Estimation and Forecasting}

In this step, the collected data for macro-ergonomics factors are ready to be used by ANFIS at the following stages:

- Choose the appropriate membership functions and inference methods

- Train the ANFIS model considering the training data set (S1)

- Evaluate the ANFIS model considering the test data set (S2)

- Apply different membership functions and inference methods for ANFIS structure

- Calculate the mean absolute percentage error (MAPE) of the each learned ANFIS structure obtained from previous step. If MAPE is less than 0.35 go to the following step; otherwise, new operators must be considered for assessment and apply previous steps again. It should be noted that this cut-off value is recommended by experts. The experts confirmed the results at this MAPE and less than it.

- Determine the optimum ANFIS architecture (ANFIS*) with the minimum MAPE by taking test data into account.

Step 6: Calculation of Outputs

In this section, outputs are calculated. ANFIS* is run for all operators, and each factor separately calculates the outputs for each operator.

Step 7: Calculation of Efficiency Scores

In this step, efficiency values are calculated. Athnassopoulos and Curram (1996) named this calculation "standard efficiency". The impact of the scale for each unit is taking into account (Azadeh et al., 2007; Costa and Markellos, 1997; Delgado, 2005). 
Error between the real output and optimum model output is calculated by ANFIS for each operator as Equation 1:

Error $_{i}=$ Output $_{\text {real }(i)}-$ Output $_{\text {ANFIS }^{*}(i)} \quad i=1, \ldots, n$

Shift frontier function is used to achieve the largest positive error. It is one of the exclusive specifications of this model (Equation 2).

Error $_{i}^{\prime}=$ Error $_{i} /$ Output $_{\text {ANFIS }^{*}(i)} \quad i=1, \ldots, n$

Assume that $k t h$ operator has the maximum Error ${ }_{i}^{\prime}($ Equation 3):

$\operatorname{Error}_{k}{ }_{k}=\max \left(\right.$ Error $\left._{i}^{\prime}\right)$

Therefore, the shift value for each operator is dissimilar and is obtained by applying Equation 4:

Shift $_{i}=$ Error $_{k}^{\prime} *$ Output $_{\text {ANFIS }^{*}(i)} /$ Output $_{\text {ANFIS }^{*}(k)} \quad i=1, \ldots, n$

Finally, efficiency values are calculated by the following equation. The efficiency scores are between 0 and 1 . Then, all operators are ranked with respect to associated efficiency scores (Equation 5).

Efficiency $_{i}=$ Output $_{\text {real }(i)} /\left(\right.$ Output $_{\text {ANFIS }^{*}(i)}+$ Shift $\left._{i}\right) \quad i=1, \ldots, n$

Step 8: Determination of Optimum Decision Style

In this step, the optimum decision style is determined based on macro-ergonomics factors by ANFIS. Three methods were used to determine the best decision style by total average efficiency (TAE). 
(1) Consider the number of operators with an efficiency value higher than TAE as N. The most frequent style in $\mathrm{N}$ is the optimal decision style.

(2) The second method uses relative frequency approach. The decision style with maximum relative frequency is an optimum decision style.

(3) The third method considers average efficiency score for each style separately. The decision style with maximum average value is the optimum style. The methodology of this study is shown in Figure 1. 


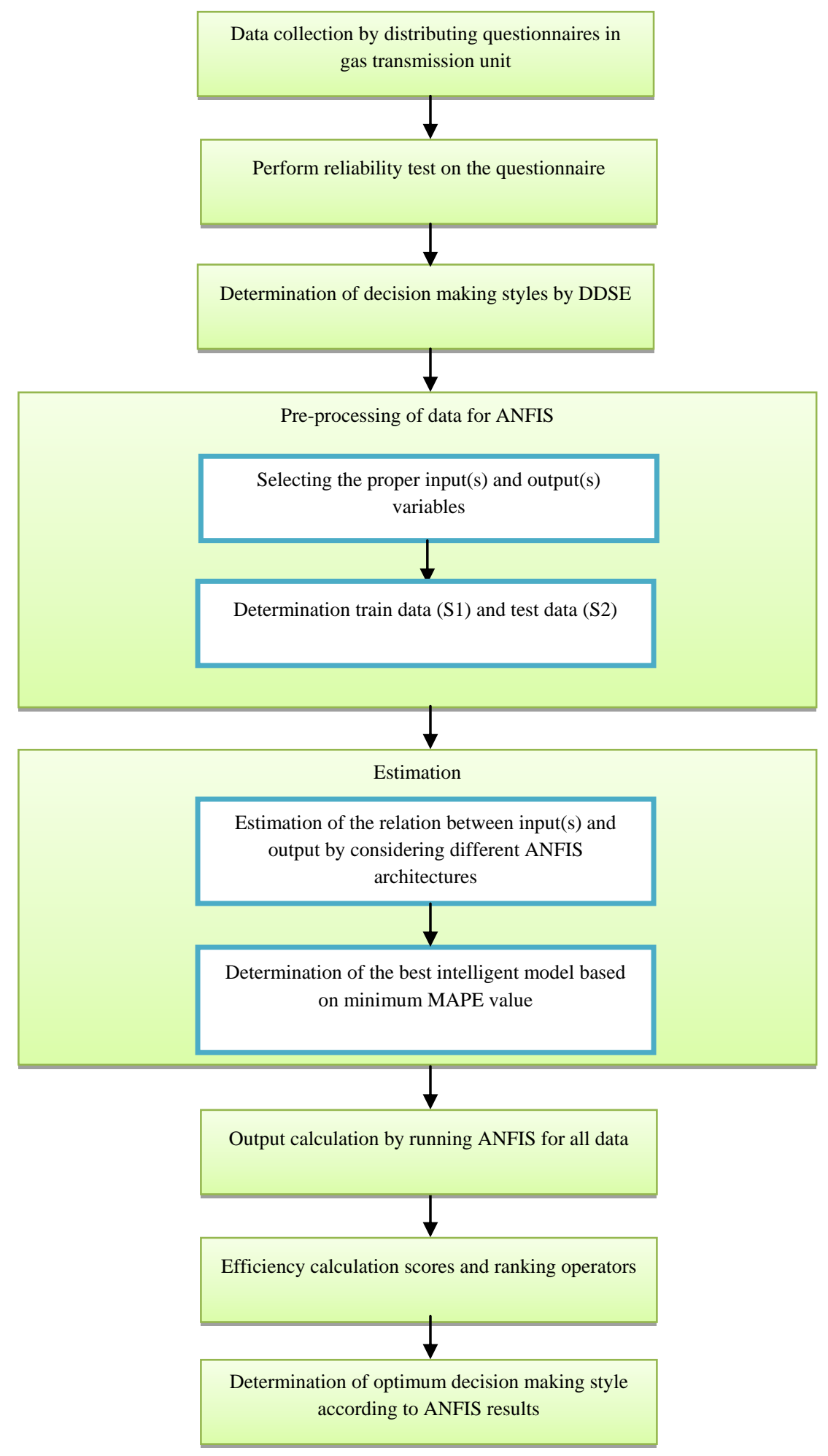

Figure 1: Flowchart of intelligent algorithm for determination of optimum decision style in context of macroergonomics factors 


\subsection{ANFIS Model}

Fuzzy systems and neural networks are widely used optimization tools in the recent decades for the complex and uncertain environments. Fuzzy logic was introduced by Zadeh (1965). Fuzzy logic uses the uncertainty theory. Neuro-fuzzy or ANFIS was proposed by Jang et al., (1997). There are different structures for neuro-fuzzy networks, including ANFIS which is one of the best approaches for Neuro-fuzzy networks (Zhou et al., 2002). ANFIS is a fuzzy approach based on neural network in which learning procedure is performed by an intelligent procedure (Shoorehdeli et al., 2009). ANFIS searches for fuzzy decision rules by a feed forward network. A fuzzy inference system (FIS) is formed by ANFIS model that membership function parameters of this model are accustomed applying the back-propagation algorithm or the least squares method. A first order Takagi-Sugeno fuzzy model by considering two inputs and one output is described in this section. It should be note that ANFIS model has a five-layered feed-forward neural structure (Azadeh et al., 2013a), and the capability of the nodes in the structure layers are defined as Equations 6 and 7:

$M_{1, i}=\alpha_{A_{i}(x)}$

$M_{1, i}=\alpha_{B_{i}(y)}$

In above Equations, Equations 6 and 7, $\mathrm{x}$ (or $\mathrm{y}$ ) is the input of node $i$, as mentioned before ANFIS uses uncertainty theory, therefore a fuzzy set is assigned to this node demonstrated by $A_{i}$ (or $\mathrm{B}_{\mathrm{i}}$ ) and $M_{i, j}$ presented the membership grade in fuzzy set, $A=A_{1}, A_{2}, B_{1}, B_{2}$.

All the parameters are consequent in the second layer, and all probable rules among the inputs are achieved by using fuzzy intersection (AND); finally, to estimate the firing strength of each rule the product operation must be applied (Equation 8). 
$M_{2, i}=\omega_{i}=\alpha_{A i(x)} \times \alpha_{B_{i}(y)} \quad i=1,2$

Furthermore, all the parameters of this layer are consequent (Equation 9).

$M_{3, i}=\bar{\omega}_{i}=\frac{\omega_{i}}{\omega_{1}+\omega_{2}} \quad i=1,2$

In the third layer, the approximation ratio of the $\boldsymbol{i}_{\mathrm{th}}$ rule's firing strength to the sum of all them is achieved through Equation 10:

$M_{4, i}=\bar{\omega}_{i} f_{i}=\bar{\omega}_{i}\left(p_{i} x+q_{i} y+r_{i}\right)$

Based on Equation 8, the third layer's output is presented by $w_{i}$. This output shows the set of parameters which are defined as consequent parameters. The overall output can be calculated through final layer by summation of all signals coming from fourth layer (Equation 11).

$M_{5,1}=\sum_{i} \bar{\omega}_{i} f_{i}=\frac{\sum_{i} \omega_{i} f_{i}}{\sum_{i} \omega_{i}}$

The measured value is an adaptive network that works as a Sugeno fuzzy model. The identification of network structure node function would be optional as long as each layer performs the pre-design function (Jang et al., 1997). Membership function (MF) is a curve that assigned a membership value between 0 and 1 to each point of input space. Different kinds of membership functions are including Triangular, Trapezoid, Gaussian, Bell, and Linear membership function. 
In this study, Gaussian MF and linear MF Default are input and output membership functions, respectively. It should be noted that all steps for ANFIS model are coded in MATLAB R2013a.

\subsection{Fuzzy Data Envelopment Analysis (FDEA)}

FDEA is a tool for the assessment of performance under uncertainty that uses fuzzy-based theories to represent and analyze uncertain data. Saati et al., (2002) presented the fuzzy version of DEA using triangulated data and reached the mathematical model shown in the Model 12 where $\tilde{x}_{i j}=\left(x_{i j}^{m}, x_{i j}^{l}, x_{i j}^{u}\right)$ and $\tilde{y}_{i j}=\left(y_{i j}^{m}, y_{i j}^{l}, y_{i j}^{u}\right)$ are the data used in the model. They proposed a new idea by Alpha cut in the FDEA version, which had been converted to definitive spaces, and selected a point in the variables of space to overcome the existing constraints and the objective function, simultaneously. The FDEA model is solved through the parametric programming considering alpha cuts. Model solution under the certain alpha cut produces the relevant performance distance for the targeted DMU.

$M \operatorname{ax} \phi+\varepsilon\left(\sum_{\mathrm{i}=1}^{2} \mathrm{~S}_{\mathrm{i}}^{-}+\sum_{r=1}^{20} s_{r}^{+}\right)$

s.t.

$\sum_{j=1}^{150} \lambda_{j}\left(x_{i j}^{m}, x_{i j}^{l}, x_{i j}^{u}\right)+s_{i}^{-}=\tilde{x}_{i o} \quad i=1,2$

$\sum_{j=1}^{150} \lambda_{j}\left(y_{r j}^{m}, y_{r j}^{l}, y_{r j}^{u}\right)-s_{r}^{+}=\phi \tilde{y}_{r o} \quad r=1,2, \ldots, 20$

$\sum_{j=1}^{150} \lambda_{j}=1$

$\lambda_{j} \geq 0$

$s_{i}^{-} \geq 0$

$s_{r}^{+} \geq 0$ 
In FDEA model, Equation (12), $x_{i j}$ shows the value of the $i_{t h}$ input for $j_{t h}$ DMU. Also, $y_{r j}$ demonstrates the value of $r_{t h}$ outputs for $j_{t h}$ DMU. There are two variables as input variables namely age and education. Moreover, 20 macro-ergonomics and integrated resilience engineering factors are considered as output variables. $\phi$ shows the efficiency score for each decision making unit. The slack variable for input and output are shown as $s_{i}^{-}$and $s_{r}^{+}$ respectively. In the first constraint, the weighted sum of fuzzy inputs must be less than $\tilde{x}_{i o}$. Also, the weighted sum of fuzzy outputs must be less than $\phi \tilde{y}_{r o}$. To apply the above FDEA model, Auto Assess $^{\circledR}$ (Azadeh et al., 2013b) is used.

\section{Case Study and Computational Results}

This study was performed in a large natural gas transmission unit consisting of 150 operators, which is located near Qom city, Iran. All the operators in control rooms constituted target sample and the questionnaires were distributed among them. In this section, the steps that explained in the methodology section were performed in order to identify the preferred decision styles with respect to macro-ergonomics and integrated resilience engineering factors in the gas transmission unit. The preferred decision styles have been determined according to macroergonomics and integrated resilience engineering factors via the efficiency values calculated by ANFIS. The ANFIS results were verified and validate considering the real data by calculation of mean absolute percentage error (MAPE).

Step 1: Standard questionnaires containing three sections were developed and presented to the operators. Operators responded to the questionnaire items about demographic information in the

first section, and the items on decision styles and macro-ergonomics in the second and third 
sections, respectively. Scores in the range of 1 to 10 (with 1 as worst and 10 as best scores) were defined to the items.

Step 2: In statistics, Cronbach's alpha is used to estimate the reliability of questionnaire as shown in Equation (13), where $n$ shows the number of questions, $s_{i}$ and $S_{t}$ illustrate the standard deviation of the ith question and total standard deviation respectively (Cronbach, 1951). Cronbach's alpha was used to prove the questionnaire validity and reliability. To this end, Cronbach's alpha for all of the research criteria (macro-ergonomics factor) was calculated to assess reliability. Reliability index lay in an acceptable level higher than 0.6 (Hsu et al., 2010) and is shown in Table 1.

Cronbach's alpha $=\frac{n}{n-1}\left(1-\frac{\sum s_{i}^{2}}{S_{t}^{2}}\right)$

Table 1: Reliability of questionnaire by Cronbach's Alpha

\begin{tabular}{|c|c|c|}
\hline Factor Number & Factor & Cronbach's Alpha \\
\hline 1 & Information flow & 0.855 \\
\hline 2 & Communication with managers & 0.629 \\
\hline 3 & Organizational regulations effectiveness & 0.904 \\
\hline 4 & Safety & 0.766 \\
\hline 5 & Violation of regulation & 0.696 \\
\hline 6 & DM speed and control ability & 0.884 \\
\hline 7 & Work pressure and stress & 0.670 \\
\hline 8 & System's efficiency & 0.747 \\
\hline 9 & Redesign & 0.770 \\
\hline 10 & Physical problem & 0.739 \\
\hline 11 & Management commitment & 0.707 \\
\hline 12 & Reporting culture & 0.703 \\
\hline 13 & Learning & 0.742 \\
\hline 14 & Awareness & 0.721 \\
\hline 15 & Preparedness & 0.818 \\
\hline 16 & Teamwork & 0.617 \\
\hline 17 & Flexibility & 0.828 \\
\hline 18 & Self-organization & 0.832 \\
\hline 19 & Fault tolerance & 0.896 \\
\hline 20 & Redundancy & 0.741 \\
\hline
\end{tabular}


According to alpha values presented in Table 1, the reliability of the questionnaire is placed in an acceptable level. Furthermore, industrial experts confirmed the gathered data.

Step 3: DDSE questionnaire was answered by 150 operators; therefore, the preferred decision styles were determined by each operator from among the main four styles as shown in Appendix 1. Frequency of each decision style is reported in Table 2.

Table 2: Frequency of decision making styles in 150 operators

\begin{tabular}{|c|c|c|c|c|}
\hline Decision making style & Decisive & Hieratic & Flexible & Integrative \\
\hline Frequency & 16 & 36 & 54 & 20 \\
\hline
\end{tabular}

There are twenty four operators with two preferred decision styles. These operators rated both styles equally and also have identical characteristics of the two styles (Table 3).

Table 3: Frequency of decision making styles in 150 operators

\begin{tabular}{|c|c|c|c|c|}
\hline Decision making style & $\begin{array}{c}\text { Flexible- } \\
\text { Integrative }\end{array}$ & $\begin{array}{c}\text { Hierarchic- } \\
\text { Flexible }\end{array}$ & $\begin{array}{c}\text { Hierarchic- } \\
\text { Decisive }\end{array}$ & $\begin{array}{c}\text { Decisive- } \\
\text { Flexible }\end{array}$ \\
\hline Frequency & 7 & 10 & 3 & 4 \\
\hline
\end{tabular}

Step 4: In this step, input(s) and output(s) of the problem are determined. There are two variables as input variables (age and education) and 20 variables of macro-ergonomics and integrated resilience engineering factors as output variables.

- The number of 150 rows of data is available obtained control room operators.

- $\quad \mathrm{S}_{1}$ and S2 indicate 130 and 20 rows of data, respectively. Usually, 70 to 90 percent of all data are belong to train set and the rest of them are applied as test set (Aznarte et al., 2007).

Step 5: The ANFIS model is trained by training data set. Then, the model is tested with 24 different structures to determine the optimum structure for this particular case study. These 24 structures and associated MAPE are shown in Table 4. 
Table 4: ANFIS architecture and MAPE values

\begin{tabular}{|c|c|c|c|c|c|}
\hline Structure \# & $\begin{array}{c}\text { And } \\
\text { method }\end{array}$ & $\begin{array}{c}\text { Or } \\
\text { method }\end{array}$ & Implication & Aggregation & MAPE \\
\hline 1 & Min & Max & Prod & Max & 0.1451 \\
\hline 2 & Prod & Max & Prod & Sum & 0.2279 \\
\hline 3 & Prod & Max & Prod & Sum & 0.2854 \\
\hline 4 & Prod & Max & Prod & Sum & 0.1513 \\
\hline 5 & Min & Max & Prod & Max & 0.1235 \\
\hline 6 & Min & Max & Prod & Max & 0.0710 \\
\hline 7 & Min & Max & Prod & Max & 0.1161 \\
\hline 8 & Prod & Max & Prod & Sum & 0.1669 \\
\hline 9 & Min & Max & Prod & Max & 0.1877 \\
\hline 10 & Prod & Max & Prod & Sum & 0.1874 \\
\hline 11 & Min & Max & Prod & Max & 0.1917 \\
\hline 12 & Prod & Max & Prod & Sum & 0.1642 \\
\hline 13 & Prod & Max & Prod & Sum & 0.3473 \\
\hline 14 & Prod & Max & Prod & Sum & 0.1990 \\
\hline 15 & Min & Max & Prod & Max & 0.1842 \\
\hline 16 & Prod & Max & Prod & Sum & 0.1481 \\
\hline 17 & Min & Max & Prod & Max & 0.1404 \\
\hline 18 & Prod & Max & Prod & Sum & 0.0734 \\
\hline 19 & Prod & Max & Prod & Sum & 0.0781 \\
\hline 20 & Min & Max & Prod & Max & 0.1221 \\
\hline
\end{tabular}

Note: Gaussmf and linear function are considered as input and output membership function respectively

Step 6: The ANFIS model is run for each output to estimate the efficiency of each operator. Figure 2 presents the distance between the actual and estimated data by ANFIS for the first output. Based on Table 2, the minimum and acceptable MAPE value for test data is 0.0710. Figure 2 shows that the proposed ANFIS model is quite close to the original data.

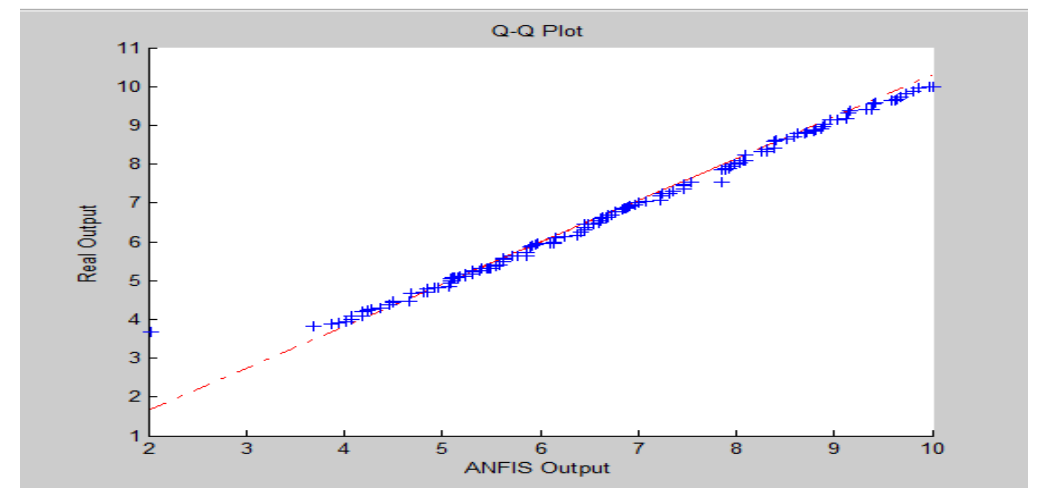

Figure 2: Q-Q plot for actual data and output calculated by ANFIS for output 1 (information flow in system) 
Step 7: Efficiency scores are now calculated. Average efficiency values for corresponding outputs along with preferred decision styles are summarized in Table 5. Furthermore, operators are ranked based on their efficiency scores.

Table 5: Average estimation of efficiency scores for each operator

\begin{tabular}{|c|c|c|c|c|c|c|c|}
\hline $\begin{array}{c}\text { Operator } \\
\text { Code } \\
\end{array}$ & $\begin{array}{c}\text { Decision } \\
\text { style }\end{array}$ & Efficiency & Rank & $\begin{array}{c}\text { Operator } \\
\text { Code }\end{array}$ & $\begin{array}{c}\text { Decision } \\
\text { style }\end{array}$ & Efficiency & Rank \\
\hline 1 & I & 1.00 & 1 & 76 & $\mathrm{H}$ & 0.72 & 118 \\
\hline 2 & I & 0.93 & 3 & 77 & $\mathrm{~F}$ & 0.77 & 66 \\
\hline 3 & D & 0.83 & 19 & 78 & $F$ & 0.72 & 119 \\
\hline 4 & $\mathrm{H}$ & 0.96 & 2 & 79 & $\mathrm{H}$ & 0.78 & 52 \\
\hline 5 & $F$ & 0.88 & 8 & 80 & D & 0.76 & 80 \\
\hline 6 & $\mathrm{~F}$ & 0.92 & 6 & 81 & $\mathrm{H}-\mathrm{F}$ & 0.82 & 23 \\
\hline 7 & I & 0.87 & 9 & 82 & H-D & 0.69 & 141 \\
\hline 8 & $\mathrm{~F}$ & 0.81 & 31 & 83 & $\mathrm{~F}$ & 0.80 & 37 \\
\hline 9 & I-F & 0.93 & 5 & 84 & I & 0.75 & 87 \\
\hline 10 & $\mathrm{D}$ & 0.86 & 11 & 85 & $\mathrm{D}$ & 0.69 & 136 \\
\hline 11 & $\mathrm{~F}$ & 0.80 & 41 & 86 & $\mathrm{H}$ & 0.78 & 54 \\
\hline 12 & $\mathrm{~F}$ & 0.80 & 35 & 87 & $\mathrm{H}$ & 0.70 & 131 \\
\hline 13 & I & 0.93 & 4 & 88 & $\mathrm{H}$ & 0.76 & 79 \\
\hline 14 & $\mathrm{~F}$ & 0.76 & 82 & 89 & $\mathrm{H}$ & 0.78 & 51 \\
\hline 15 & $\mathrm{~F}$ & 0.74 & 103 & 90 & $\mathrm{I}$ & 0.78 & 57 \\
\hline 16 & $\mathrm{D}$ & 0.87 & 10 & 91 & $\mathrm{~F}$ & 0.74 & 101 \\
\hline 17 & $\mathrm{H}$ & 0.77 & 67 & 92 & $\mathrm{D}$ & 0.68 & 142 \\
\hline 18 & $\mathrm{H}$ & 0.65 & 147 & 93 & $\mathrm{~F}$ & 0.73 & 110 \\
\hline 19 & $\mathrm{~F}$ & 0.75 & 96 & 94 & $\mathrm{H}$ & 0.82 & 22 \\
\hline 20 & $\mathrm{D}$ & 0.75 & 85 & 95 & $\mathrm{I}$ & 0.76 & 84 \\
\hline 21 & $\mathrm{D}$ & 0.78 & 58 & 96 & $\mathrm{D}$ & 0.72 & 122 \\
\hline 22 & $\mathrm{~F}$ & 0.73 & 112 & 97 & $\mathrm{H}$ & 0.77 & 71 \\
\hline 23 & D-F & 0.75 & 88 & 98 & $\mathrm{I}$ & 0.74 & 105 \\
\hline 24 & $\mathrm{I}$ & 0.72 & 121 & 99 & $\mathrm{H}$ & 0.75 & 99 \\
\hline 25 & $\mathrm{~F}$ & 0.81 & 28 & 100 & $\mathrm{~F}$ & 0.76 & 72 \\
\hline 26 & $\mathrm{H}$ & 0.85 & 13 & 101 & $\mathrm{I}$ & 0.76 & 74 \\
\hline 27 & $\mathrm{~F}$ & 0.80 & 42 & 102 & $\mathrm{~F}$ & 0.76 & 73 \\
\hline 28 & I & 0.83 & 17 & 103 & $\mathrm{H}$ & 0.70 & 135 \\
\hline 29 & $\mathrm{H}$ & 0.77 & 63 & 104 & $\mathrm{H}$ & 0.75 & 93 \\
\hline 30 & $\mathrm{~F}$ & 0.82 & 26 & 105 & $\mathrm{D}$ & 0.74 & 109 \\
\hline 31 & $\mathrm{~F}$ & 0.90 & 7 & 106 & I & 0.75 & 90 \\
\hline 32 & F-I & 0.84 & 14 & 107 & $\mathrm{~F}$ & 0.77 & 62 \\
\hline 33 & $\mathrm{~F}$ & 0.78 & 56 & 108 & $\mathrm{I}$ & 0.70 & 133 \\
\hline 34 & $\mathrm{~F}$ & 0.81 & 30 & 109 & $\mathrm{~F}$ & 0.81 & 27 \\
\hline 35 & H-F & 0.82 & 24 & 110 & $\mathrm{H}$ & 0.76 & 75 \\
\hline 36 & $\mathrm{~F}$ & 0.83 & 16 & 111 & F-I & 0.75 & 95 \\
\hline 37 & D-H & 0.76 & 76 & 112 & F-I & 0.71 & 130 \\
\hline 38 & $\mathrm{H}$ & 0.78 & 53 & 113 & $\mathrm{~F}$ & 0.75 & 94 \\
\hline 39 & $\mathrm{H}$ & 0.82 & 21 & 114 & $\mathrm{I}$ & 0.63 & 149 \\
\hline 40 & $\mathrm{H}$ & 0.69 & 139 & 115 & $\mathrm{~F}$ & 0.80 & 43 \\
\hline 41 & H-F & 0.79 & 45 & 116 & $\mathrm{H}$ & 0.71 & 127 \\
\hline 42 & $\mathrm{H}$ & 0.79 & 46 & 117 & $\mathrm{~F}$ & 0.74 & 108 \\
\hline 43 & H-F & 0.77 & 68 & 118 & $\mathrm{H}-\mathrm{F}$ & 0.79 & 49 \\
\hline
\end{tabular}




\begin{tabular}{|c|c|c|c|c|c|c|c|}
\hline 44 & $\mathrm{~F}$ & 0.85 & 12 & 119 & $\mathrm{~F}$ & 0.71 & 125 \\
\hline 45 & $\mathrm{~F}$ & 0.80 & 33 & 120 & $\mathrm{~F}$ & 0.75 & 98 \\
\hline 46 & $\mathrm{~F}$ & 0.80 & 39 & 121 & $\mathrm{~F}$ & 0.83 & 18 \\
\hline 47 & $\mathrm{~F}$ & 0.80 & 34 & 122 & I & 0.72 & 124 \\
\hline 48 & $\mathrm{D}$ & 0.80 & 40 & 123 & $F$ & 0.78 & 50 \\
\hline 49 & $\mathrm{~F}$ & 0.79 & 48 & 124 & H-F & 0.69 & 138 \\
\hline 50 & $\mathrm{H}$ & 0.80 & 44 & 125 & $\mathrm{~F}$ & 0.76 & 81 \\
\hline 51 & $\mathrm{D}$ & 0.82 & 25 & 126 & H-F & 0.76 & 78 \\
\hline 52 & $\mathrm{~F}$ & 0.80 & 38 & 127 & $F$ & 0.77 & 65 \\
\hline 53 & $\mathrm{H}$ & 0.76 & 83 & 128 & H-F & 0.74 & 100 \\
\hline 54 & $\mathrm{~F}$ & 0.77 & 69 & 129 & $\mathrm{H}$ & 0.69 & 137 \\
\hline 55 & F-I & 0.73 & 111 & 130 & $F$ & 0.75 & 92 \\
\hline 56 & $\mathrm{H}$ & 0.77 & 61 & 131 & $F$ & 0.74 & 107 \\
\hline 57 & $\mathrm{~F}$ & 0.82 & 20 & 132 & D-F & 0.68 & 143 \\
\hline 58 & D & 0.80 & 36 & 133 & F-I & 0.73 & 113 \\
\hline 59 & $\mathrm{H}$ & 0.83 & 15 & 134 & $F$ & 0.75 & 97 \\
\hline 60 & F-I & 0.74 & 104 & 135 & $\mathrm{~F}$ & 0.77 & 70 \\
\hline 61 & $\mathrm{~F}$ & 0.81 & 29 & 136 & H-D & 0.73 & 116 \\
\hline 62 & $\mathrm{H}$ & 0.72 & 117 & 137 & $\mathrm{~F}$ & 0.72 & 123 \\
\hline 63 & $\mathrm{H}$ & 0.79 & 47 & 138 & D-F & 0.74 & 106 \\
\hline 64 & $\mathrm{H}$ & 0.71 & 128 & 139 & I & 0.64 & 148 \\
\hline 65 & D & 0.73 & 114 & 140 & $\mathrm{H}-\mathrm{F}$ & 0.67 & 145 \\
\hline 66 & D & 0.80 & 32 & 141 & $\mathrm{~F}$ & 0.73 & 115 \\
\hline 67 & $\mathrm{~F}$ & 0.77 & 59 & 142 & $\mathrm{H}$ & 0.70 & 134 \\
\hline 68 & $\mathrm{H}$ & 0.78 & 55 & 143 & $\mathrm{H}$ & 0.66 & 146 \\
\hline 69 & $\mathrm{~F}$ & 0.77 & 64 & 144 & $\mathrm{~F}$ & 0.74 & 102 \\
\hline 70 & I & 0.70 & 132 & 145 & $\mathrm{H}-\mathrm{F}$ & 0.71 & 129 \\
\hline 71 & $\mathrm{H}$ & 0.71 & 126 & 146 & $\mathrm{~F}$ & 0.77 & 60 \\
\hline 72 & I & 0.72 & 120 & 147 & $\mathrm{~F}$ & 0.68 & 144 \\
\hline 73 & $\mathrm{H}$ & 0.75 & 91 & 148 & D-F & 0.75 & 86 \\
\hline 74 & I & 0.76 & 77 & 149 & I & 0.63 & 150 \\
\hline 75 & $\mathrm{H}$ & 0.75 & 89 & 150 & D & 0.69 & 140 \\
\hline
\end{tabular}

Note: $\mathrm{D}=$ Decisive, $\mathrm{H}=$ Hieratic, $\mathrm{F}=$ Flexible, I=Integrative

Step 8: In this step, optimum decision styles are identified in the context of macro-ergonomics factors. The three methods are applied to determine the optimum decision style for each position.

(1) Average efficiency value is 0.7676 . Hence, the number of 65 operators is selected to identify the optimum decision style. According to this method, flexible decision style is the most frequent style with a frequency of 36 operators. Therefore, flexible style is the optimum decision style in this method for each job position at this unit.

(2) Moreover, according to the second method, the maximum relative frequency belongs to flexible decision style. 
(3) By incorporating the third method, the total average value is calculated for each style. Maximum average value is obtained equal to 0.774 for flexible decision style. Similarly, flexible style is also the optimum decision style in this method.

As a result, according to the stated three methods, flexible DM style for control room operators of the gas transmission unit is the optimum style. The individuals with flexible DM style have multiple concentration abilities and use information when required. The flexible operator has pertinent ability to make his/her decision rapidly. The whole information has various interpretations and definitions to such operators. Thus, a flexible operator, in the face of an event, chooses several solutions rapidly. When a flexible operator understands that the current approach is not suitable, s/he will quickly opt for another method.

Flexible managers use a balanced level of information and value performance, speed, consistency and diversity to achieve a sense of security and acceptability from the lens of others. Furthermore, flexible individuals with maximum ability of expressing creativity and accordance favor unstructured work. They are uninterested in rigid and inflexible structures and regulations. These people are intuitive, compatible, and fast; however, they suffer from some disadvantages such as low focus, lack of planning and opposition to structuralism.

\subsection{Validation and Verification}

In this step, FDEA approach is applied in order to validate the results obtained in the previous step. To achieve this goal, fuzzy DEA model is employed due to the uncertainty of the data. In this model, age and education level are considered as input variables and macroergonomic and integrated resilience engineering factors as output variables. This model is executed for 10 alpha levels, among which the model with the highest average efficiency is selected as the best model. The average efficiencies of these models have been shown in Figure 
3. As can be seen, Alpha value of 0.1 is selected as the best model to performance evaluation since it has the highest average efficiency. After calculating efficiencies and ranking them at this alpha, the spearman correlation was done between the ranks from DEA model and ANFIS model to validate the obtained results. The correlation coefficient value is obtained 0.763 which shows the existence of a significance relationship between the two models. Therefore, it can be concluded that the FDEA results validate the results of ANFIS model.

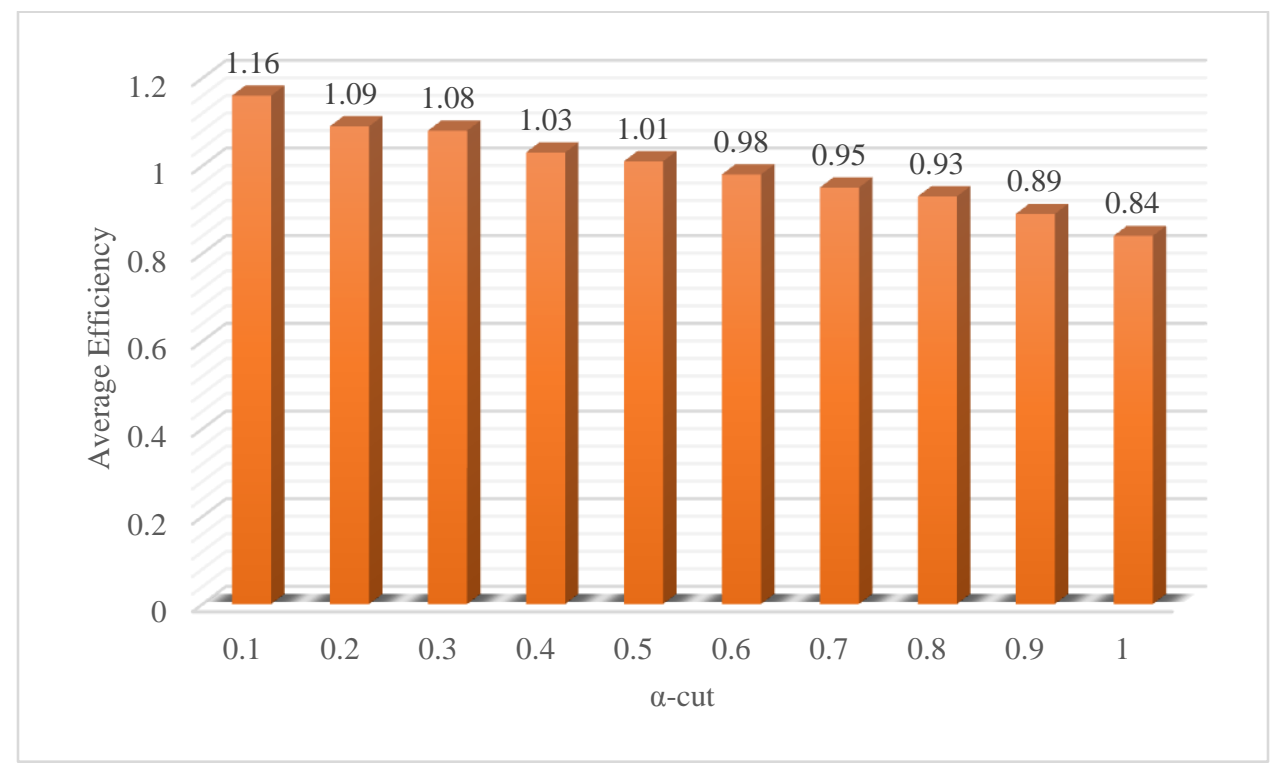

Figure 3: Average efficiencies of the fuzzy envelopment analysis at different $\alpha$-cut levels

\subsection{Sensitivity Analysis}

In this study, two variables, i.e. education and age are used as inputs while 20 macroergonomics and integrated resilience engineering factors are considered as outputs. Moreover, the sensitivity of input variables is analyzed by running ANFIS. In this regard, first, efficiency values are calculated by running ANFIS model while considering "age" as the only input for all 20 outputs. Then, the same procedure is repeated for "education". In addition, ANFIS is executed with no input but the inclusion of all 20 outputs. Moreover, dummy variables are used 
to calculate efficiency values for all outputs. Results are evaluated by statistical analysis in order to compare their effects. In summary, there are 4 models to be compared and analyzed: 1) Running ANFIS with two inputs (referred to as model 1), 2) Running ANFIS with "age" input (referred to as model 2), 3) Running ANFIS with "educational level” input (referred to as model 3) and 4) running ANFIS with dummy variables (referred to as model 4). These models are only defined to show the impact of the education and age on the operator's performance. It is important that DM identify the significance inputs on operator's performance. To do this, 4 models, as stated above, are considered to investigate the importance degree of the inputs.

Table 6 shows the correlation coefficients between model 1 and the other ones for this particular case study. The results demonstrates that there is a strong correlation between model 1 and the other models. To extend the analysis further, paired t-test was also performed between model 1 and all the others to show the impact of the input variables. Table 7 shows the results of paired t-test. Moreover, the null hypothesis was accepted which means that there is no significant difference between model 1 and the other ones. In the same way, age and education have no impact on operators' performance.

Table 6: Correlation between model 1 and other models

\begin{tabular}{|c|c|c|c|}
\hline & $\mathrm{N}$ & $\begin{array}{c}\text { Correlation } \\
\text { coefficient }\end{array}$ & $\mathrm{p}$-value \\
\hline Pair 1 Model 1\& Model 2 & 150 & 0.987 & 0.000 \\
\hline Pair 2 Model 1 \&Model 3 & 150 & 0.977 & 0.000 \\
\hline Pair 3 Model 1 \&Model 4 & 150 & 0.971 & 0.000 \\
\hline
\end{tabular}


Table 7: Paired t-test between model 1 and other models

\begin{tabular}{|c|c|c|c|c|c|c|c|c|}
\hline & \multicolumn{5}{|c|}{ Paired Difference } & \multirow{3}{*}{$\mathrm{t}$-value } & \multirow{3}{*}{$\begin{array}{l}\text { Degree } \\
\text { of } \\
\text { freedom }\end{array}$} & \multirow{3}{*}{ P-value } \\
\hline & \multirow[t]{2}{*}{ Mean } & \multirow[t]{2}{*}{$\begin{array}{l}\text { Standard } \\
\text { Deviation }\end{array}$} & \multirow{2}{*}{$\begin{array}{l}\text { Standard } \\
\text { Error } \\
\text { Mean }\end{array}$} & \multicolumn{2}{|c|}{$\begin{array}{l}95 \% \text { Confidence } \\
\text { Interval of the } \\
\text { Difference }\end{array}$} & & & \\
\hline & & & & Lower & Upper & & & \\
\hline $\begin{array}{l}\text { Pair } 1 \text { Model } 1 \\
\& \text { Model } 2\end{array}$ & -0.00100 & 0.00995 & 0.00081 & -0.00261 & 0.00061 & -1.231 & 149 & 0.220 \\
\hline $\begin{array}{c}\text { Pair } 2 \text { Model } 1 \\
\& \text { Model } 3\end{array}$ & 0.00113 & 0.01314 & 0.00107 & -0.00099 & 0.00325 & 1.057 & 149 & 0.292 \\
\hline $\begin{array}{c}\text { Pair } 3 \text { Model } 1 \\
\text { \&Model } 4 \\
\end{array}$ & -0.00173 & 0.01469 & 0.00120 & -0.00410 & 0.00064 & -1.445 & 149 & 0.150 \\
\hline
\end{tabular}

According to the average efficiency values for each factor in Table 8, information flow, safety, system efficiency and redesign require more attention. Hence, these factors are analyzed according to computational results and specifications of dominant and optimum style in this unit. Flexible individuals are quick in DM and have proper connections with other people (Driver et al., 1998). "DM speed" and "violation of regulations" factors are the most influential factors for this particular case study as shown in Table 8 and Figure 4.

Table 8: Average efficiency of operators for each output variable (ANFIS model)

\begin{tabular}{|c|c|c|}
\hline Factor number & Factor of macro-ergonomics & Average efficiency value \\
\hline 1 & Information flow & 0.70 \\
\hline 2 & Communication with managers & 0.76 \\
\hline 3 & Organizational regulations effectiveness & 0.78 \\
\hline 4 & Safety & 0.70 \\
\hline 5 & Violation of regulation & 0.86 \\
\hline 6 & DM speed and control ability & 0.86 \\
\hline 7 & Work pressure and stress & 0.79 \\
\hline 8 & System's efficiency & 0.70 \\
\hline 9 & Teamwork & 0.80 \\
\hline 10 & Flexibility & 0.82 \\
\hline 11 & Self-organization & 0.82 \\
\hline 12 & Redesign & 0.70 \\
\hline 13 & Physical problem & 0.72 \\
\hline 14 & Management commitment & 0.84 \\
\hline 15 & Reporting culture & 0.80 \\
\hline 16 & Awareness & 0.79 \\
\hline 17 & Preparedness & 0.70 \\
\hline 18 & Redundancy & 0.76 \\
\hline
\end{tabular}


Table 8: Average efficiency of operators for each output variable (ANFIS model)

\begin{tabular}{|c|c|c|}
\hline Factor number & Factor of macro-ergonomics & Average efficiency value \\
\hline 19 & Fault tolerance & 0.75 \\
\hline 20 & Learning & 0.71 \\
\hline
\end{tabular}

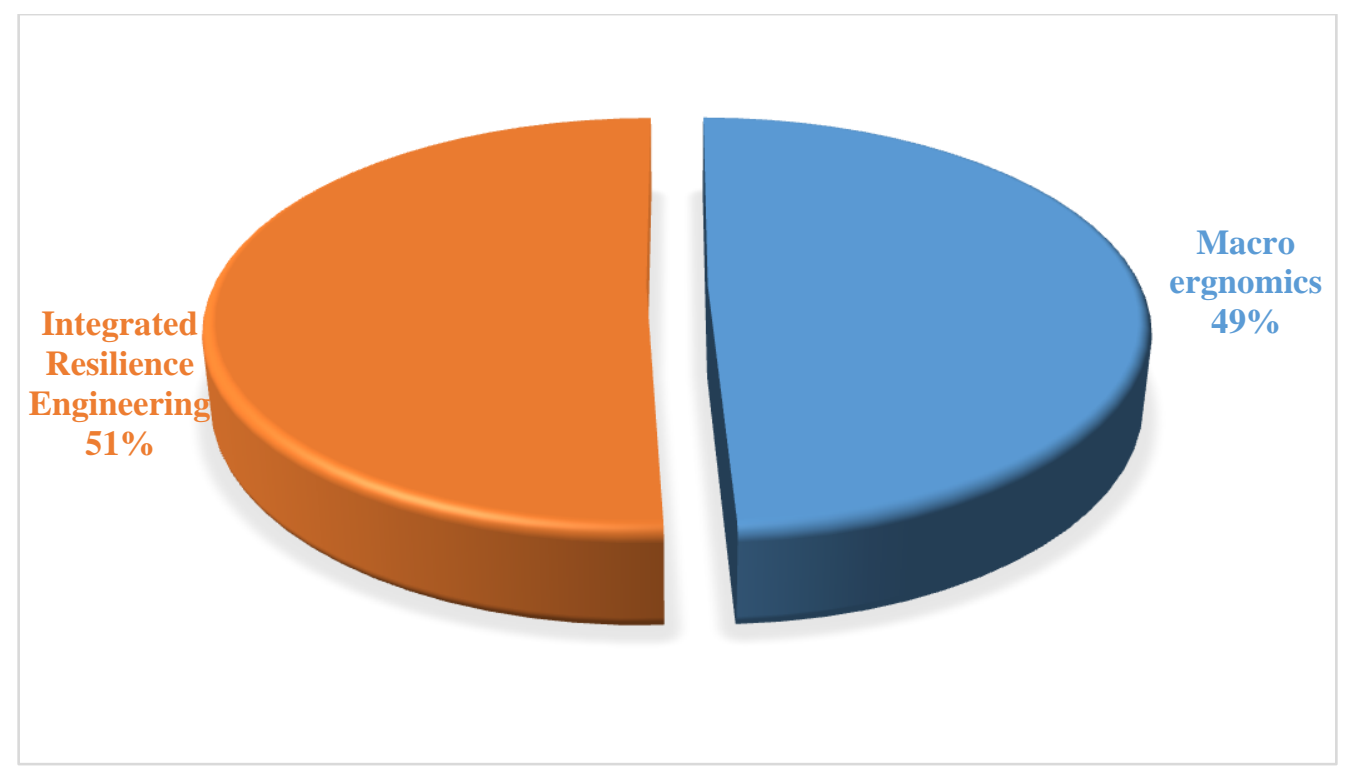

Figure 4: Percentage of average efficiency of operators for each output category

\section{Conclusion}

This paper aimed to optimize operators' performance with respect to their decision styles in the context of macro-ergonomics and resilience engineering in an actual gas transmission unit in Iran. To this end, the operators' efficiency values were calculated based on macro-ergonomics and integrated resilience engineering factors by means of ANFIS wherein age and education of operators were considered as inputs, and macro-ergonomics factors were considered as outputs. The results revealed that flexible DM style is the optimum style for control room operators of the gas transmission unit. Additionally, the conduct of sensitivity analysis suggested that input variables, including age and education, had no significant impact on operators' performance. However, information flow, safety, system efficiency, redesign, preparedness, and learning require more attention and have the lowest efficiency values amongst macro-ergonomics and 
integrated resilience engineering factors; and DM speed and violation of regulations factors exuded the best results in this gas transmission unit. To demonstrate advantages and superiorities of our study, features of this study are compared with previous models and studies as shown in Table 9.

Table 9: The proposed approach versus other studies

\begin{tabular}{|c|c|c|c|c|c|c|c|c|}
\hline \multirow[b]{2}{*}{ Studies } & \multicolumn{8}{|c|}{ Features } \\
\hline & $\begin{array}{l}\text { Considering } \\
\text { decision } \\
\text { styles }\end{array}$ & $\begin{array}{c}\text { Data } \\
\text { complexity } \\
\text { and non- } \\
\text { linearity }\end{array}$ & $\begin{array}{l}\text { Macroergonomics } \\
\text { factors }\end{array}$ & $\begin{array}{l}\text { Resilience } \\
\text { engineering }\end{array}$ & $\begin{array}{c}\text { Sensitivity } \\
\text { analysis }\end{array}$ & $\begin{array}{l}\text { Identification } \\
\text { of important } \\
\text { factors }\end{array}$ & Uncertainty & Optimization \\
\hline This study & $\checkmark$ & $\checkmark$ & $\checkmark$ & $\checkmark$ & $\checkmark$ & $\checkmark$ & $\checkmark$ & $\checkmark$ \\
\hline $\begin{array}{l}\text { Jamian et al. } \\
\text { (2013) }\end{array}$ & $\checkmark$ & & & & & & & $\checkmark$ \\
\hline $\begin{array}{l}\text { Piegorsch et } \\
\text { al. (2006) }\end{array}$ & $\checkmark$ & & & & & & & \\
\hline $\begin{array}{c}\text { Fox and } \\
\text { Spence } \\
\text { (1999) }\end{array}$ & & $\checkmark$ & $\checkmark$ & & & & & $\checkmark$ \\
\hline $\begin{array}{c}\text { Azadeh et al. } \\
(2014)\end{array}$ & & $\checkmark$ & & $\checkmark$ & $\checkmark$ & & & $\checkmark$ \\
\hline
\end{tabular}

\section{References}

Amazt, I. H., \& Idris, A. R. (2011). Lecturers' Satisfaction towards University Management \& Decisionmaking Styles in some Malaysian Public Universities. Procedia-Social and Behavioral Sciences, 15, 3957-3970.

Asadzadeh, S. M., Azadeh, A., Negahban, A., \& Sotoudeh, A. (2013). Assessment and improvement of integrated HSE and macro-ergonomics factors by fuzzy cognitive maps: The case of a large gas refinery. Journal of Loss Prevention in the Process Industries, 26(6), 1015-1026.

Athanassopoulos, A. D., \& Curram, S. P. (1996). A comparison of data envelopment analysis and artificial neural networks as tools for assessing the efficiency of decision making units. Journal of the Operational Research Society, 1000-1016. 
Azadeh, A., Gaeini, Z., \& Moradi, B. (2014). Optimization of HSE in maintenance activities by integration of continuous improvement cycle and fuzzy multivariate approach: A gas refinery. Journal of Loss Prevention in the Process Industries, 32, 415-427.

Azadeh, A., Ghaderi, S. F., Anvari, M., \& Saberi, M. (2007). Performance assessment of electric power generations using an adaptive neural network algorithm. Energy Policy, 35(6), 3155-3166.

Azadeh, A., Ghaderi, S. F., Anvari, M., Izadbakhsh, H. R., Rezaee, M. J., \& Raoofi, Z. (2013b). An integrated decision support system for performance assessment and optimization of decisionmaking units. The International Journal of Advanced Manufacturing Technology, 66(5-8), 10311045.

Azadeh, A., Mohammad Fam, I., Sadjadi, M., Hamidi, Y., \& Kianfar, A. (2008). An integrated and multivariate model along with designing experiments approach for assessment of micro-and macro-ergonomics factors: the case of a gas refinery. Journal of Research in Health Sciences, 8(2), 28-39.

Azadeh, A., Rouzbahman, M., Saberi, M., \& Fam, I. M. (2011). An adaptive neural network algorithm for assessment and improvement of job satisfaction with respect to HSE and ergonomics program: the case of a gas refinery. Journal of Loss Prevention in the Process Industries, 24(4), 361-370.

Azadeh, A., Rouzbahman, M., Saberi, M., \& Valianpour, F. (2014a). An adaptive algorithm for assessment of operators with job security and HSEE indicators. Journal of Loss Prevention in the Process Industries, 31, 26-40.

Azadeh, A., Saberi, M., Rouzbahman, M., \& Saberi, Z. (2013). An intelligent algorithm for performance evaluation of job stress and HSE factors in petrochemical plants with noise and uncertainty. Journal of Loss Prevention in the Process Industries, 26(1), 140-152.

Azadeh, A., Salehi, V., Ashjari, B., \& Saberi, M. (2014). Performance evaluation of integrated resilience engineering factors by data envelopment analysis: The case of a petrochemical plant. Process Safety and Environmental Protection, 92(3), 231-241.

Azadeh, A., Sharahi, Z. J., Ashjari, B., \& Saberi, M. (2013a). A flexible intelligent algorithm for identification of optimum mix of demographic variables for integrated HSEE-ISO systems: The case of a gas transmission refinery. Journal of Loss Prevention in the Process Industries, 26(6), 1159-1182.

Baiocco, R., Laghi, F., \& D'Alessio, M. (2009). Decision-making style among adolescents: Relationship with sensation seeking and locus of control. Journal of Adolescence, 32(4), 963-976.

Cooper, D. R., \& Schindler, P. S. (2003). Business research methods.

Costa, Á., \& Markellos, R. N. (1997). Evaluating public transport efficiency with neural network models. Transportation Research Part C: Emerging Technologies, 5(5), 301-312. 
Cronbach, L. J. (1951). Coefficient alpha and the internal structure of tests. Psychometrika, 16(3), 297334.

Curşeu, P. L., \& Schruijer, S. G. (2012). Decision Styles and Rationality an Analysis of the Predictive Validity of the General Decision-Making Style Inventory. Educational and Psychological Measurement, 72(6), 1053-1062.

Delgado, F. J. (2005). Measuring efficiency with neural networks, an application to the public sector. Economics Bulletin, 3(15), 1-10.

Deveci, M., Demirel, N. Ç., John, R., \& Özcan, E. (2015). Fuzzy multi-criteria decision making for carbon dioxide geological storage in Turkey. Journal of Natural Gas Science and Engineering, In press.

Dewberry, C., Juanchich, M., \& Narendran, S. (2013). Decision-making competence in everyday life: The roles of general cognitive styles, decision-making styles and personality. Personality and Individual Differences, 55(7), 783-788.

Driver, M. (1991). Decision styles, Overview of 20 years research, University of Southern California, Decision Dynamics Corporation, Santa Monica, California.

Driver, M. J., Brousseau, K. R., \& Hunsaker, P. L. (1998). The dynamic decision maker: Five decision styles for executive and business success. IUniverse.

Fox, T. L., \& Spence, J. W. (1999). An examination of the decision styles of project managers: evidence of significant diversity. Information \& management, 36(6), 313-320.

Galotti, K. M., Ciner, E., Altenbaumer, H. E., Geerts, H. J., Rupp, A., \& Woulfe, J. (2006). Decisionmaking styles in a real-life decision: Choosing a college major. Personality and Individual Differences, 41(4), 629-639.

Gandhi, O. P. (2011). Quantification of human error in maintenance using graph theory and matrix approach. Quality and Reliability Engineering International, 27(8), 1145-1172.

Hallock, M. L., Alper, S. J., \& Karsh, B. (2006). A macro-ergonomic work system analysis of the diagnostic testing process in an outpatient health care facility for process improvement and patient safety. Ergonomics, 49(5-6), 544-566.

Hendrick, H. W. (1995, October). Humanizing re-engineering for true organizational effectiveness: a macro-ergonomic approach. In Proceedings of the Human Factors and Ergonomics Society Annual Meeting (Vol. 39, No. 12, pp. 761-765). SAGE Publications.

Hendrick, H. W. (2005). An overview of macro-ergonomics. Ergonomics: The history and scope of human factors, 1,38 .

Hendrick, H. W., \& Kleiner, B. M. (1999). Macro-ergonomics: An introduction to work system design. 
Hsu, S. H., Lee, C. C., Wu, M. C., and Takano, K. (2010).The influence of organizational factors on safety in Taiwanese high-risk industries, Journal of Loss Prevention in the Process Industries, 23, 646-653.

Jamian, L. S., Sidhu, G. K., \& Aperapar, P. S. (2013). Managerial decision styles of deans in institutions of higher learning. Procedia-Social and Behavioral Sciences, 90, 278-287.

Jang, J. S. R., Sun, C. T., \& Mizutani, E. (1997). Neuro-fuzzy and soft computing; a computational approach to learning and machine intelligence.

Khandan, M., Vosoughi, S., \& Maghsoudipour, M. (2012). Evaluation of safety climate factors-a macroergonomics approach: a case study in Iran. Iranian Rehabilitation Journal, 10, 43-46.

Kjellén, U. (2000). Prevention of accidents through experience feedback. CRC Press.

Lee, K. S. (2005). Ergonomics in total quality management: How can we sell ergonomics to management? Ergonomics, 48(5), 547-558.

Luczak, H. (1995). Macro-ergonomic anticipatory evaluation of work organization in production systems. Ergonomics, 38(8), 1571-1599.

Michelsen, F. A., Halvorsen, I. J., \& Lund, B. F. (2010). The impact of process design decisions on operability and control of an LNG process. Journal of Natural Gas Science and Engineering, 2(4), 183-191.

Morel, G., Amalberti, R., \& Chauvin, C. (2009). How good micro/macro ergonomics may improve resilience, but not necessarily safety. Safety Science, 47(2), 285-294.

Öngen, D. E. (2014). Vocational Identity Status among Turkish Youth: Relationships between Perfectionisms and Decision Making Style. Procedia-Social and Behavioral Sciences, 116, 472476.

Pasmore, W. A. (1988). Designing effective organizations: The sociotechnical systems perspective (Vol. 6). John Wiley \& Sons Inc.

Piegorsch, K. M., Watkins, K. W., Piegorsch, W. W., Reininger, B., Corwin, S. J., \& Valois, R. F. (2006). Ergonomic decision-making: A conceptual framework for experienced practitioners from backgrounds in industrial engineering and physical therapy. Applied ergonomics, 37(5), 587-598.

Saati, S. M., Memariani, A., \& Jahanshahloo, G. R. (2002). Efficiency analysis and ranking of DMUs with fuzzy data. Fuzzy Optimization and Decision Making, 1(3), 255-267.

Scott, S. G., \& Bruce, R. A. (1995). Decision-making style: The development and assessment of a new measure. Educational and psychological measurement, 55(5), 818-831. 
Shoorehdeli, M. A., Teshnehlab, M., Sedigh, A. K., \& Khanesar, M. A. (2009). Identification using ANFIS with intelligent hybrid stable learning algorithm approaches and stability analysis of training methods. Applied Soft Computing, 9(2), 833-850.

Tang, Y., Zou, Z., Jing, J., Zhang, Z., \& Xie, C. (2015). A framework for making maintenance decisions for oil and gas drilling and production equipment. Journal of Natural Gas Science and Engineering, 26, 1050-1058.

Wood, N. L., \& Highhouse, S. (2014). Do self-reported decision styles relate with others' impressions of decision quality? Personality and Individual Differences, 70, 224-228.

Woodson, W. E., Tillman, B., \& Tillman, P. (1992). Human factors design handbook: information and guidelines for the design of systems, facilities, equipment, and products for human use.

Wreathall, J. (2006). Properties of resilient organizations: an initial view. Resilience engineering concepts and precepts. In: Hollnagel, E., Woods, D., Leveson, N. (Eds.), Resilience Engineering: Concepts and Precepts. Ashgate, Aldershot, UK, pp. 275-286.

Zadeh, L. A. (1965). Fuzzy sets. Information and control, 8(3), 338-353.

Zhou, Y., Li, S., \& Jin, R. (2002). A new fuzzy neural network with fast learning algorithm and guaranteed stability for manufacturing process control. Fuzzy sets and systems, 132(2), 201-216. 
Appendix 1: The related characteristics of individual differences and task attributes in a typical crisis situation

\begin{tabular}{|c|c|c|c|c|}
\hline \multirow{2}{*}{$\begin{array}{l}\text { Attributes and } \\
\text { Characteristics }\end{array}$} & \multicolumn{4}{|c|}{ Decision Styles } \\
\hline & Decisive & Flexible & Hierarchic & Integrative \\
\hline Time pressure & 4 & 3 & 2 & 1 \\
\hline Task overload & 4 & 3 & 2 & 1 \\
\hline Task complexity & 1 & 1 & 4 & 4 \\
\hline Task uncertainty & 1 & 4 & 1 & 4 \\
\hline Speed in task & 4 & 3 & 2 & 1 \\
\hline $\begin{array}{l}\text { Involvement of others in } \\
\text { a group }\end{array}$ & 2 & 4 & 3 & 4 \\
\hline Negative stress & 2 & 4 & 2 & 4 \\
\hline $\begin{array}{l}\text { Amount of interaction } \\
\text { with others }\end{array}$ & 2 & 4 & 3 & 4 \\
\hline Logical reasoning & 2 & 1 & 4 & 3 \\
\hline $\begin{array}{l}\text { Ability to have an } \\
\text { impact on system }\end{array}$ & 1 & 2 & 3 & 4 \\
\hline $\begin{array}{l}\text { Preference for analytical } \\
\text { reasoning }\end{array}$ & 1 & 3 & 4 & 3 \\
\hline $\begin{array}{l}\text { Preference for several } \\
\text { methods }\end{array}$ & 1 & 4 & 2 & 4 \\
\hline $\begin{array}{l}\text { Utilizing creativity \& } \\
\text { intuition }\end{array}$ & 1 & 3 & 2 & 4 \\
\hline Using rules \& scripts & 4 & 2 & 4 & 1 \\
\hline Unfamiliarity & 1 & 3 & 2 & 4 \\
\hline $\begin{array}{l}\text { Span of control of } \\
\text { operators }\end{array}$ & 2 & 4 & 3 & 4 \\
\hline $\begin{array}{l}\text { Amount of power of } \\
\text { operators }\end{array}$ & 4 & 2 & 3 & 1 \\
\hline Planning demand & 2 & 1 & 4 & 3 \\
\hline $\begin{array}{l}\text { Confusion with other } \\
\text { events }\end{array}$ & 1 & 3 & 2 & 4 \\
\hline $\begin{array}{l}\text { Confusion in dealing } \\
\text { with switches }\end{array}$ & 1 & 3 & 2 & 4 \\
\hline
\end{tabular}

1= Poor Performance

2= Average to Weak Performance

3= Good Performance

4= Excellent Performance 


\section{Appendix II: Questionnaire of measuring macro-ergonomics factors}

\begin{tabular}{|c|c|c|c|}
\hline & Row & Question & Rating \\
\hline \multirow{13}{*}{ Information flow } & 1 & How do you assess information circulation between your department and others? & \\
\hline & 2 & Do you receive the work-related information from related managers and bosses? & \\
\hline & 3 & Do you receive the work-related information from colleagues, properly? & \\
\hline & 4 & Are the existing information systems impact on your work rate? & \\
\hline & 5 & Are the existing information systems impact on your work efficiency? & \\
\hline & 6 & Are the existing information systems impact on organizational control? & \\
\hline & 7 & Are the existing information systems impact on identifying corrective actions? & \\
\hline & 8 & Are the existing information systems impact on improving services? & \\
\hline & 9 & $\begin{array}{l}\text { How do you assess the harmony of skill needs for work with information systems with } \\
\text { your skill level, ability and expertise? }\end{array}$ & \\
\hline & 10 & How do you assess the familiarity to enter data, extract, correct and edit information? & \\
\hline & 11 & How much are incoming messages telling and understandable for you? & \\
\hline & 12 & How much sufficient information about the types of error messages are given? & \\
\hline & 13 & $\begin{array}{l}\text { How do you assess the consistency of long and short-term objectives in the field of } \\
\text { information systems with long and short-term goals of organization? }\end{array}$ & \\
\hline \multirow{2}{*}{$\begin{array}{l}\text { Communication } \\
\text { with managers } \\
\text { and supervisors }\end{array}$} & 14 & How do you assess your ease of communication with managers and supervisors? & \\
\hline & 15 & How do you assess your ease of communication with colleagues in the organization? & \\
\hline \multirow{3}{*}{$\begin{array}{c}\text { Effectiveness of } \\
\text { the } \\
\text { organizational } \\
\text { rules }\end{array}$} & 16 & How much are you familiar with the written rules and regulations of organization? & \\
\hline & 17 & $\begin{array}{l}\text { How do you evaluate the implementation of written laws and regulations of } \\
\text { organization? }\end{array}$ & \\
\hline & 18 & How much are you familiar with the organization's hierarchy? & \\
\hline \multirow{10}{*}{ Safety } & 19 & $\begin{array}{l}\text { How the placement of tables, chairs and equipment can cause accident and danger during } \\
\text { job? }\end{array}$ & \\
\hline & 20 & How do you assess the nature of your work for the danger and injury? & \\
\hline & 21 & How do you assess the possibility of an accident due to harassment out of workplace? & \\
\hline & 22 & How much using safety devices available is necessary? & \\
\hline & 23 & How do you feel comfortable when using safety devices? & \\
\hline & 24 & How do you assess the replacement of safety parts at your workplace? & \\
\hline & 25 & How do you assess the replacement of old and new parts? & \\
\hline & 26 & How do you assess the working area in terms of free and comfortable movement? & \\
\hline & 27 & How do you assess the risk of fire and explosion at your workplace? & \\
\hline & 28 & How do you assess the speed and precision of working with devices? & \\
\hline \multirow{2}{*}{$\begin{array}{l}\text { Violation of } \\
\text { regulations }\end{array}$} & 29 & $\begin{array}{l}\text { How much do you think complying with the laws and regulations of the organization is } \\
\text { necessary? }\end{array}$ & \\
\hline & 30 & How much do you use the instructions to do works? & \\
\hline \multirow{5}{*}{$\begin{array}{l}\text { Speed of decision } \\
\text { making and } \\
\text { control ability }\end{array}$} & 31 & How do you assess the concentration during your work? & \\
\hline & 32 & How do you assess your responsibility during your work? & \\
\hline & 33 & How do you assess the speed of decision making during your work? & \\
\hline & 34 & How do you assess your experience and learning power during your work? & \\
\hline & 35 & How do you assess the power and skill of control during your work? & \\
\hline
\end{tabular}




\begin{tabular}{|c|c|c|}
\hline $\begin{array}{c}\text { Working } \\
\text { pressure and job } \\
\text { stress }\end{array}$ & 36 & How do you assess the stress at work? \\
\hline \multirow{3}{*}{ Redesign } & 37 & $\begin{array}{l}\text { In your opinion, to what extent can better design the workplace to provide more comfort } \\
\text { and safety for you? }\end{array}$ \\
\hline & 38 & How do you assess the arrangement of devices in your workplace? \\
\hline & 39 & In your opinion, how much the organization is in need of improvement? \\
\hline \multirow{5}{*}{$\begin{array}{c}\text { System } \\
\text { performance }\end{array}$} & 40 & How do you assess the people expertise in their duties in the organization? \\
\hline & 41 & How do you assess management cooperation in line with organizational goals? \\
\hline & 42 & How do you assess the written procedures in your organization? \\
\hline & 43 & $\begin{array}{l}\text { How effective are quality management system / safety and health / environment in your } \\
\text { performance? }\end{array}$ \\
\hline & 44 & How helpful are training courses for you? \\
\hline \multirow{5}{*}{$\begin{array}{l}\text { Physical } \\
\text { problems }\end{array}$} & 45 & How much do you feel pain or fatigue during the job? \\
\hline & 46 & How much is breathing bothering for you in the workplace? \\
\hline & 47 & How the sound of your workplace is bothering for you? \\
\hline & 48 & How do you evaluate the intensity of light in your workplace? \\
\hline & 49 & How do you evaluate the temperature of the workplace? \\
\hline \multirow{3}{*}{ Teamwork } & 50 & When the workload is high, do the staff help each other? \\
\hline & 51 & Do the employees correct each other's mistakes to pursue the programs appropriately? \\
\hline & 52 & Do staff share their information for timely decision-making in your unit? \\
\hline \multirow{3}{*}{ Flexibility } & 53 & Is there with multiple skills human resources to work at emergency situations? \\
\hline & 54 & $\begin{array}{l}\text { Do the equipment and machineries have the flexibility to prevent or deal with sudden } \\
\text { accidents? }\end{array}$ \\
\hline & 55 & Do you have all scarce resources to deal with sudden events? (Materials, time, etc.) \\
\hline \multirow{2}{*}{ Self-organization } & 56 & $\begin{array}{l}\text { Does the organizational structure give you special powers to deal with sudden events to } \\
\text { make decisions without the hierarchy? }\end{array}$ \\
\hline & 57 & $\begin{array}{l}\text { If the system is suddenly faced with a problem, do you have authority - from the boss - } \\
\text { to decide? (e.g. stopping the production line) }\end{array}$ \\
\hline \multirow{4}{*}{$\begin{array}{l}\text { Management } \\
\text { commitment }\end{array}$} & 58 & Do you appreciate your staff? \\
\hline & 59 & Do you think your boss is grateful for your work? \\
\hline & 60 & Can you stop the production line if safety is in danger? \\
\hline & 61 & Do you encourage your employees to stop the production line if safety is at risk? \\
\hline \multirow{3}{*}{$\begin{array}{l}\text { Reporting } \\
\text { culture }\end{array}$} & 62 & Are you able to easily report safety problems to the boss? \\
\hline & 63 & Do your employees to easily report issues and safety problems? \\
\hline & 64 & Do you help your staff to improve the status of their works? \\
\hline \multirow{4}{*}{ Learning } & 65 & Do you feel that there is discussing about risks in the company or work? \\
\hline & 66 & Are the accidents feedback or review being distributed throughout the organization? \\
\hline & 67 & $\begin{array}{l}\text { Do you think the organization's past successes guarantee future success of the } \\
\text { organization? }\end{array}$ \\
\hline & 68 & Do you think there is enough training in your organization? \\
\hline \multirow{4}{*}{ Awareness } & 69 & Will the company expect you to follow several goals simultaneously (safety, cost, ...)? \\
\hline & 70 & Is the quality and safety levels depend on the amount of funding? \\
\hline & 71 & Is the safety programs offered to employees? \\
\hline & 72 & Do you think that know what is going on now in your organization? \\
\hline
\end{tabular}




\begin{tabular}{|c|c|l|l|}
\hline \multirow{5}{*}{ Preparedness } & 73 & Do you think that all staff are aware of safety issues? & $\begin{array}{l}\text { Do you think your programs and safety awareness, is sufficient to deal with future } \\
\text { issues? }\end{array}$ \\
\cline { 2 - 5 } & 75 & $\begin{array}{l}\text { Do you prepare for overcoming the future problems by conducting safety workshops and } \\
\text { group meetings? }\end{array}$ & $\begin{array}{l}\text { Do you appreciate if your staff consult you about future trends or hazards based on their } \\
\text { feelings? }\end{array}$ \\
\cline { 2 - 5 } Redundancy & 77 & $\begin{array}{l}\text { Is there an alternative when one of the critical components of the system (parts, } \\
\text { machines, servers, software, etc.) faced with a problem or failure? }\end{array}$ & \\
\cline { 2 - 5 } & 78 & $\begin{array}{l}\text { Are the operators of critical part of a system (such as control room operators) have } \\
\text { multiple capabilities so that if an operator fails, the operator temporarily do his work? }\end{array}$ & \\
\hline \multirow{5}{*}{ Fault tolerance } & 79 & $\begin{array}{l}\text { Can the entire system continue to operate when one of the critical parts or components of } \\
\text { the system (parts, machines, servers, software, etc.) faced with a problem or failure? }\end{array}$ & \\
\cline { 2 - 5 } & 80 & $\begin{array}{l}\text { Can the system continue to operate until a certain time period when one of the critical } \\
\text { parts or components of the system (parts, machines, servers, software, etc.) faced with a } \\
\text { problem or failure? }\end{array}$ & \\
\hline
\end{tabular}


Appendix III: Raw data

\begin{tabular}{|c|c|c|c|c|c|c|c|c|c|c|c|c|c|c|c|c|c|c|c|c|c|c|}
\hline 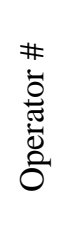 & $\underset{<}{\infty}$ & : & 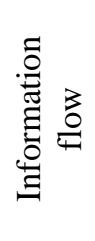 & 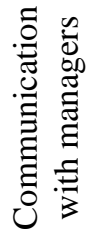 & 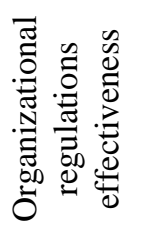 & 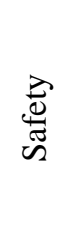 & 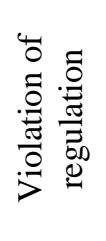 & 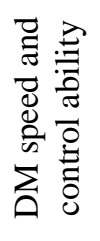 & 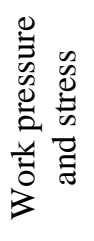 & 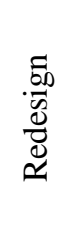 & 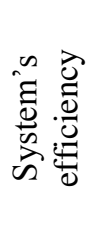 & 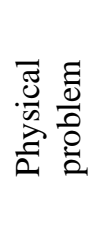 & 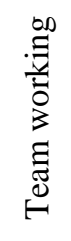 & 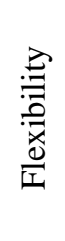 & 岇 & 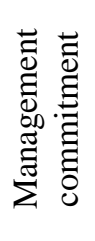 & 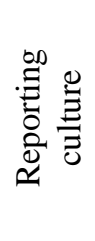 & 泀 & 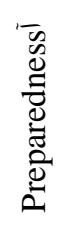 & 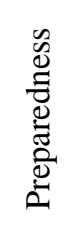 & 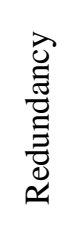 & 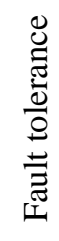 \\
\hline 1 & 10 & 10 & 10 & 9.7 & 7.6 & 10 & 8.7 & 8.3 & 6.5 & 5.8 & 4 & 4.5 & 6.6 & 5 & 5.5 & 8.5 & 10 & 10 & 10 & 9.7 & 7.6 & 10 \\
\hline 2 & 8.5 & 10 & 10 & 9 & 7.8 & 8 & 8.7 & 7.7 & 3 & 5.3 & 5 & 6 & 7 & 6.3 & 6.5 & 6.5 & 8.5 & 10 & 10 & 9 & 7.8 & 8 \\
\hline 3 & 8 & 7.4 & 5 & 5.7 & 5.8 & 5.6 & 7.3 & 6.3 & 3 & 4.8 & 5 & 5 & 5 & 5.7 & 5 & 5.5 & 8 & 7.4 & 5 & 5.7 & 5.8 & 5.6 \\
\hline 4 & 7.5 & 8.6 & 10 & 6 & 7.6 & 7.4 & 7.3 & 7.3 & 5.5 & 6.5 & 4.7 & 6 & 6.6 & 7.3 & 8.5 & 6.5 & 7.5 & 8.6 & 10 & 6 & 7.6 & 7.4 \\
\hline 5 & 8.5 & 7.2 & 9 & 6.3 & 4.8 & 7 & 8 & 6 & 4.5 & 4.8 & 4.3 & 5.3 & 7.2 & 7.3 & 5.5 & 10 & 8.5 & 7.2 & 9 & 6.3 & 4.8 & 7 \\
\hline 6 & 8 & 9.4 & 7 & 9 & 7 & 7.8 & 9.3 & 7 & 5 & 5.3 & 5 & 6 & 5.2 & 5.3 & 9.5 & 6.5 & 8 & 9.4 & 7 & 9 & 7 & 7.8 \\
\hline 7 & 7 & 10 & 10 & 9.7 & 7.6 & 8 & 6 & 7.3 & 4.5 & 5.5 & 4 & 4.8 & 5.4 & 6.7 & 5.5 & 6 & 7 & 10 & 10 & 9.7 & 7.6 & 8 \\
\hline 8 & 6.5 & 8.8 & 6 & 6.3 & 5.2 & 7.2 & 9.3 & 6.7 & 3 & 4.5 & 4 & 5 & 7.2 & 6.3 & 9 & 7 & 6.5 & 8.8 & 6 & 6.3 & 5.2 & 7.2 \\
\hline 9 & 8 & 10 & 10 & 9.7 & 7.6 & 8 & 7.7 & 7.3 & 6.5 & 5.3 & 4 & 5 & 6.4 & 6.7 & 6.5 & 6.5 & 8 & 10 & 10 & 9.7 & 7.6 & 8 \\
\hline 10 & 6.5 & 7.6 & 9 & 6.3 & 6.2 & 7.6 & 6.3 & 6.7 & 8 & 5 & 2.7 & 5.5 & 6 & 6 & 9 & 9 & 6.5 & 7.6 & 9 & 6.3 & 6.2 & 7.6 \\
\hline 11 & 8.5 & 7.6 & 5 & 5.3 & 6.2 & 3.8 & 7.7 & 3.7 & 9 & 4.8 & 6.7 & 7 & 5.4 & 6 & 8.5 & 8 & 8.5 & 7.6 & 5 & 5.3 & 6.2 & 3.8 \\
\hline 12 & 8 & 8 & 5 & 5.7 & 6.2 & 3.4 & 8.7 & 5 & 8.5 & 5 & 6.3 & 5.8 & 6 & 6.7 & 5 & 8.5 & 8 & 8 & 5 & 5.7 & 6.2 & 3.4 \\
\hline 13 & 7 & 7.8 & 10 & 9.3 & 10 & 6.6 & 7.3 & 6.7 & 6 & 8 & 7 & 6.8 & 7 & 4 & 9.5 & 8 & 7 & 7.8 & 10 & 9.3 & 10 & 6.6 \\
\hline 14 & 8 & 8 & 4 & 7 & 6 & 5.4 & 8.7 & 6 & 7 & 5 & 5.7 & 5 & 5.8 & 5 & 8.5 & 6.5 & 8 & 8 & 4 & 7 & 6 & 5.4 \\
\hline 15 & 6.5 & 8 & 4 & 7 & 6 & 5.4 & 7.7 & 5.3 & 3.5 & 4.5 & 5.3 & 6.5 & 6.4 & 6.3 & 7 & 7.5 & 6.5 & 8 & 4 & 7 & 6 & 5.4 \\
\hline 16 & 7.5 & 9.2 & 10 & 7 & 7.6 & 9.4 & 8 & 7.7 & 8 & 6.8 & 5.7 & 6.3 & 7.6 & 6 & 7 & 10 & 7.5 & 9.2 & 10 & 7 & 7.6 & 9.4 \\
\hline 17 & 9 & 7.8 & 6 & 7.3 & 5 & 5.8 & 8 & 5.3 & 3 & 4.3 & 7 & 5.3 & 7.4 & 6.3 & 6.5 & 6 & 9 & 7.8 & 6 & 7.3 & 5 & 5.8 \\
\hline 18 & 7.5 & 6 & 3 & 5.3 & 6.6 & 1.4 & 8 & 4.7 & 3.5 & 5 & 4.7 & 4.5 & 6 & 6 & 6.5 & 7.5 & 7.5 & 6 & 3 & 5.3 & 6.6 & 1.4 \\
\hline 19 & 8.5 & 8.4 & 9 & 6.7 & 5.2 & 7.8 & 5.7 & 6.7 & 5.5 & 6.3 & 5.7 & 4.5 & 6.8 & 5 & 7 & 7.5 & 8.5 & 8.4 & 9 & 6.7 & 5.2 & 7.8 \\
\hline 20 & 7.5 & 8.4 & 8 & 8 & 5.8 & 6.8 & 6.3 & 5 & 5 & 4.5 & 4.3 & 4.5 & 7 & 6 & 7.5 & 7.5 & 7.5 & 8.4 & 8 & 8 & 5.8 & 6.8 \\
\hline 21 & 8.5 & 6.6 & 10 & 5 & 8.6 & 7 & 3.3 & 6.7 & 2.5 & 4.3 & 6.7 & 3.8 & 6 & 8 & 8.5 & 6 & 8.5 & 6.6 & 10 & 5 & 8.6 & 7 \\
\hline 22 & 7.5 & 7.8 & 9 & 5.7 & 6.6 & 5.4 & 6.3 & 5 & 5 & 4.8 & 5.3 & 3.5 & 5.6 & 7.7 & 7.5 & 7.5 & 7.5 & 7.8 & 9 & 5.7 & 6.6 & 5.4 \\
\hline
\end{tabular}




\begin{tabular}{|c|c|c|c|c|c|c|c|c|c|c|c|c|c|c|c|c|c|c|c|c|c|c|}
\hline 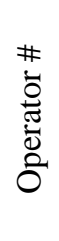 & $\stackrel{8}{\mathbb{R}}$ & 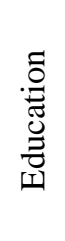 & 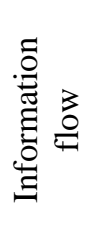 & 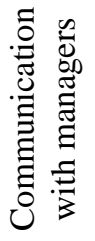 & 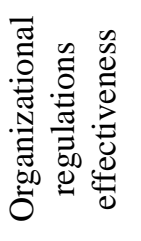 & 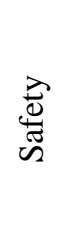 & 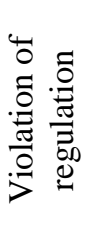 & 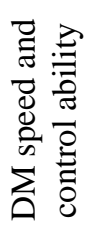 & 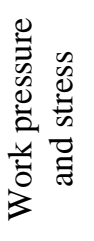 & 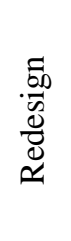 & 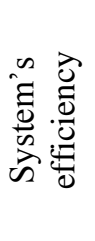 & 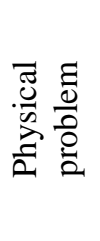 & 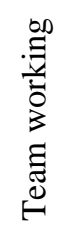 & 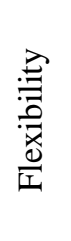 & 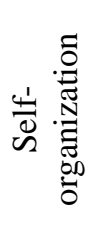 & 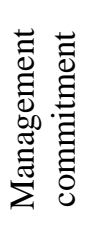 & 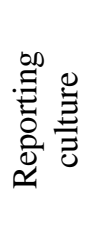 & . & 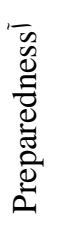 & 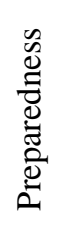 & 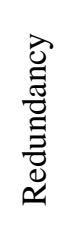 & 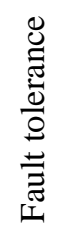 \\
\hline 23 & 7 & 8.2 & 9 & 5.7 & 5.2 & 6.4 & 7 & 5.7 & 4.5 & 3.8 & 5 & 4 & 7.8 & 6.3 & 9 & 8.5 & 7 & 8.2 & 9 & 5.7 & 5.2 & 6.4 \\
\hline 24 & 9 & 9.2 & 6 & 7.3 & 5.2 & 4.8 & 4.3 & 4 & 4 & 6.3 & 2.3 & 5.3 & 6 & 6 & 7 & 5.5 & 9 & 9.2 & 6 & 7.3 & 5.2 & 4.8 \\
\hline 25 & 7.5 & 7.8 & 9 & 7.3 & 7.2 & 6.8 & 5.3 & 6 & 5 & 6.5 & 6 & 6.8 & 7.4 & 6 & 8.5 & 7 & 7.5 & 7.8 & 9 & 7.3 & 7.2 & 6.8 \\
\hline 26 & 7.5 & 9.4 & 8 & 8.3 & 8.2 & 7.6 & 5.7 & 7.3 & 3 & 7.5 & 5.3 & 5.5 & 6.2 & 7 & 8.5 & 10 & 7.5 & 9.4 & 8 & 8.3 & 8.2 & 7.6 \\
\hline 27 & 8 & 9 & 5 & 7 & 6.4 & 3.8 & 5.7 & 4 & 5.5 & 5 & 5.7 & 4.5 & 6 & 6.3 & 9 & 8.5 & 8 & 9 & 5 & 7 & 6.4 & 3.8 \\
\hline 28 & 8.5 & 9 & 10 & 7 & 4.4 & 8.8 & 8.3 & 7 & 5.5 & 3.8 & 5.7 & 4.8 & 7.6 & 7 & 8 & 7.5 & 8.5 & 9 & 10 & 7 & 4.4 & 8.8 \\
\hline 29 & 7.5 & 9 & 5 & 5.7 & 7.4 & 2.4 & 6 & 5 & 6.5 & 4.3 & 4.7 & 4.8 & 6.4 & 4.3 & 8.5 & 7 & 7.5 & 9 & 5 & 5.7 & 7.4 & 2.4 \\
\hline 30 & 8 & 9 & 8 & 6.7 & 7.8 & 5.8 & 5.7 & 4.3 & 5.5 & 6 & 4.3 & 4 & 5 & 7.7 & 7 & 6.5 & 8 & 9 & 8 & 6.7 & 7.8 & 5.8 \\
\hline 31 & 6.5 & 10 & 10 & 10 & 10 & 7.6 & 5.7 & 5.7 & 6.5 & 5.5 & 8.3 & 6.3 & 5.6 & 7.7 & 9.5 & 7 & 6.5 & 10 & 10 & 10 & 10 & 7.6 \\
\hline 32 & 8 & 10 & 10 & 7.7 & 8.4 & 5.2 & 6 & 5 & 7 & 4.8 & 5.7 & 6.3 & 5 & 6 & 8 & 7 & 8 & 10 & 10 & 7.7 & 8.4 & 5.2 \\
\hline 33 & 7.5 & 8.8 & 8 & 7 & 8 & 6 & 5.3 & 6 & 3.5 & 5 & 7 & 5 & 5.6 & 7 & 9.5 & 6.5 & 7.5 & 8.8 & 8 & 7 & 8 & 6 \\
\hline 34 & 8.5 & 8.2 & 10 & 7.3 & 7.2 & 7.8 & 6 & 7.3 & 3.5 & 6.3 & 4.3 & 5.3 & 4.8 & 6 & 6 & 8 & 8.5 & 8.2 & 10 & 7.3 & 7.2 & 7.8 \\
\hline 35 & 7 & 7.2 & 9 & 8.7 & 8.4 & 8.2 & 6 & 7.7 & 4.5 & 5 & 4.7 & 4.5 & 4.4 & 7.7 & 7.5 & 6 & 7 & 7.2 & 9 & 8.7 & 8.4 & 8.2 \\
\hline 36 & 7 & 8.8 & 10 & 7.3 & 9 & 6.8 & 7.7 & 5.3 & 6 & 4.8 & 3.7 & 5.8 & 5.2 & 6.7 & 9 & 8.5 & 7 & 8.8 & 10 & 7.3 & 9 & 6.8 \\
\hline 37 & 7 & 8.4 & 8 & 6 & 5.6 & 6 & 7.7 & 8.3 & 4 & 6.3 & 5.7 & 6.5 & 5.2 & 6.3 & 9 & 9 & 7 & 8.4 & 8 & 6 & 5.6 & 6 \\
\hline 38 & 6.5 & 7.4 & 8 & 7.7 & 5.6 & 7 & 4.3 & 5.7 & 4 & 6.3 & 6 & 5.8 & 7 & 5.3 & 7 & 7.5 & 6.5 & 7.4 & 8 & 7.7 & 5.6 & 7 \\
\hline 39 & 7.5 & 7.6 & 9 & 7.7 & 5.4 & 7.6 & 5.7 & 5 & 7 & 5.8 & 5.3 & 5.5 & 5.4 & 5.7 & 9 & 9 & 7.5 & 7.6 & 9 & 7.7 & 5.4 & 7.6 \\
\hline 40 & 7 & 8.2 & 9 & 4.7 & 3.8 & 5 & 6 & 6.3 & 5.5 & 5 & 5.3 & 6.8 & 5.8 & 5.7 & 7.5 & 7 & 7 & 8.2 & 9 & 4.7 & 3.8 & 5 \\
\hline 41 & 7.5 & 6 & 6 & 7.7 & 7.8 & 4.4 & 5 & 6.7 & 7.5 & 7.3 & 6.3 & 4.8 & 6.2 & 7.3 & 8 & 9.5 & 7.5 & 6 & 6 & 7.7 & 7.8 & 4.4 \\
\hline 42 & 7.5 & 9 & 9 & 7 & 6.2 & 5.6 & 6.3 & 4.7 & 6.5 & 5.8 & 6 & 5.8 & 6 & 6.3 & 9 & 6 & 7.5 & 9 & 9 & 7 & 6.2 & 5.6 \\
\hline 43 & 6.5 & 8.4 & 6 & 7 & 6.4 & 7 & 6.3 & 5.7 & 3 & 5.8 & 2.7 & 4.5 & 6 & 6 & 8.5 & 8 & 6.5 & 8.4 & 6 & 7 & 6.4 & 7 \\
\hline 44 & 7.5 & 8 & 7 & 7.7 & 9 & 7 & 6.7 & 5.3 & 3.5 & 6.3 & 4.7 & 6.5 & 7.2 & 7.7 & 8 & 9 & 7.5 & 8 & 7 & 7.7 & 9 & 7 \\
\hline 45 & 7 & 8 & 8 & 7.7 & 6.8 & 6.2 & 7 & 5.3 & 6 & 7.3 & 5.7 & 4.8 & 5.2 & 5.7 & 7 & 7.5 & 7 & 8 & 8 & 7.7 & 6.8 & 6.2 \\
\hline
\end{tabular}




\begin{tabular}{|c|c|c|c|c|c|c|c|c|c|c|c|c|c|c|c|c|c|c|c|c|c|c|}
\hline 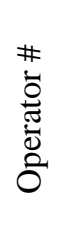 & $\stackrel{8}{\mathbb{L}}$ & 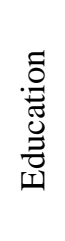 & 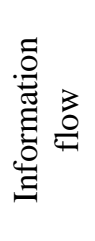 & 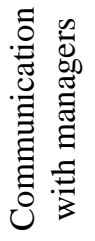 & 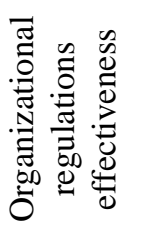 & 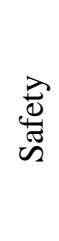 & 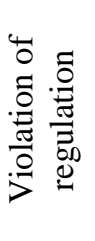 & 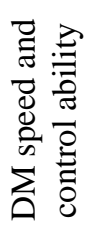 & 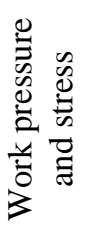 & 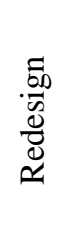 & 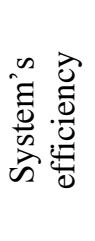 & 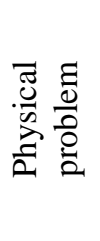 & 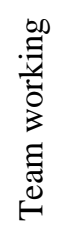 & 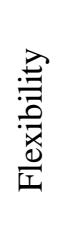 & 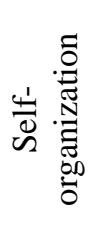 & 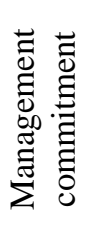 & 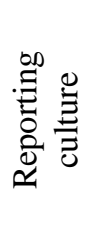 & . & 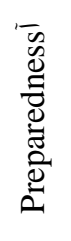 & 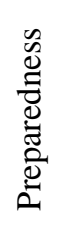 & 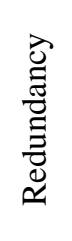 & 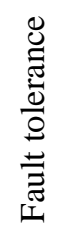 \\
\hline 46 & 9 & 7 & 9 & 8 & 6.6 & 8 & 6.3 & 6.7 & 4 & 6.5 & 4 & 4.5 & 4.8 & 6.3 & 6.5 & 7 & 9 & 7 & 9 & 8 & 6.6 & 8 \\
\hline 47 & 7.3 & 8.6 & 5.4 & 6.8 & 9.2 & 6.6 & 6.6 & 6.4 & 6.9 & 4.6 & 5.3 & 5.8 & 5.7 & 6.1 & 9 & 8 & 7.3 & 8.6 & 5.4 & 6.8 & 9.2 & 6.6 \\
\hline 48 & 7.9 & 6.5 & 9.7 & 6.3 & 7.8 & 9.5 & 7.8 & 6.7 & 4.3 & 6.9 & 3.1 & 3.8 & 5.5 & 6.1 & 5.4 & 6.7 & 7.9 & 6.5 & 9.7 & 6.3 & 7.8 & 9.5 \\
\hline 49 & 8.2 & 8.8 & 3.1 & 5.4 & 4.6 & 6 & 6.1 & 6.2 & 6.6 & 4.9 & 4.7 & 5.4 & 6.1 & 8 & 8 & 6.4 & 8.2 & 8.8 & 3.1 & 5.4 & 4.6 & 6 \\
\hline 50 & 9.6 & 7.1 & 4.4 & 8.4 & 7.7 & 9.3 & 4.7 & 4.2 & 7.5 & 4 & 3.8 & 4.2 & 6.2 & 8 & 5 & 7.8 & 9.6 & 7.1 & 4.4 & 8.4 & 7.7 & 9.3 \\
\hline 51 & 9.3 & 9.9 & 7.2 & 8.7 & 6.7 & 7.3 & 5.5 & 7.6 & 8 & 7.3 & 4.7 & 5.6 & 4.6 & 7.6 & 7.9 & 6.3 & 9.3 & 9.9 & 7.2 & 8.7 & 6.7 & 7.3 \\
\hline 52 & 7.7 & 9.7 & 3.9 & 7.8 & 7.3 & 5.1 & 8 & 8.2 & 5.5 & 6.5 & 7.9 & 4.8 & 6.2 & 5.3 & 9 & 7.8 & 7.7 & 9.7 & 3.9 & 7.8 & 7.3 & 5.1 \\
\hline 53 & 8 & 9.3 & 3.3 & 10 & 3.8 & 1.7 & 3.9 & 6.9 & 6.4 & 3.9 & 7.7 & 5.2 & 6.7 & 5.8 & 6.9 & 8.8 & 8 & 9.3 & 3.3 & 10 & 3.8 & 1.7 \\
\hline 54 & 8 & 7.5 & 5.7 & 6.8 & 7.6 & 7 & 7.1 & 4.1 & 4.9 & 6.3 & 3.9 & 4.2 & 7 & 5 & 9.2 & 7.3 & 8 & 7.5 & 5.7 & 6.8 & 7.6 & 7 \\
\hline 55 & 6.6 & 6.9 & 4.5 & 7.4 & 7.3 & 4.8 & 8.5 & 4.7 & 3.3 & 5.2 & 4.2 & 4.6 & 5 & 6.8 & 6.8 & 6.3 & 6.6 & 6.9 & 4.5 & 7.4 & 7.3 & 4.8 \\
\hline 56 & 7 & 7.5 & 8.3 & 9.5 & 4 & 7.2 & 6.7 & 6.4 & 7.2 & 4.6 & 7 & 4.5 & 6.6 & 4.3 & 5.3 & 9.8 & 7 & 7.5 & 8.3 & 9.5 & 4 & 7.2 \\
\hline 57 & 6.7 & 6 & 6.4 & 9.2 & 9 & 2.5 & 3.9 & 5.5 & 9 & 7.3 & 8 & 6.5 & 7 & 7.8 & 9.2 & 5.6 & 6.7 & 6 & 6.4 & 9.2 & 9 & 2.5 \\
\hline 58 & 8.1 & 8 & 6.2 & 5.5 & 4.8 & 8.4 & 8.7 & 5.4 & 7.5 & 7.7 & 6.5 & 5.2 & 6 & 7.5 & 8.8 & 8.4 & 8.1 & 8 & 6.2 & 5.5 & 4.8 & 8.4 \\
\hline 59 & 7.2 & 9.9 & 6.4 & 9.3 & 8.9 & 6.5 & 6.4 & 5 & 7 & 6.8 & 6.5 & 6.6 & 5.3 & 6.9 & 7.9 & 6.6 & 7.2 & 9.9 & 6.4 & 9.3 & 8.9 & 6.5 \\
\hline 60 & 8.6 & 8 & 4.9 & 8.8 & 6.3 & 6.9 & 6.3 & 5.6 & 7.4 & 3.8 & 5 & 4.2 & 6.9 & 6.9 & 8 & 6.5 & 8.6 & 8 & 4.9 & 8.8 & 6.3 & 6.9 \\
\hline 61 & 9.9 & 7.7 & 7.1 & 6.7 & 8.5 & 1.9 & 6.6 & 7.7 & 8.3 & 4.2 & 6 & 4.9 & 5.1 & 6.3 & 8.5 & 8.5 & 9.9 & 7.7 & 7.1 & 6.7 & 8.5 & 1.9 \\
\hline 62 & 6.7 & 8.2 & 5.2 & 4.7 & 4.8 & 8.3 & 4.7 & 4.3 & 7.1 & 4.9 & 5.1 & 4.2 & 7.5 & 6.8 & 8.3 & 8 & 6.7 & 8.2 & 5.2 & 4.7 & 4.8 & 8.3 \\
\hline 63 & 9.1 & 9.3 & 7.6 & 4.9 & 7.9 & 6.6 & 8.9 & 7.5 & 4.7 & 7.7 & 5.4 & 5.2 & 4.7 & 5.6 & 5.5 & 9.6 & 9.1 & 9.3 & 7.6 & 4.9 & 7.9 & 6.6 \\
\hline 64 & 8.9 & 6.3 & 6.2 & 6 & 4 & 2.7 & 5 & 8.3 & 8.4 & 6.6 & 5.5 & 4.8 & 7.3 & 5 & 7.5 & 6 & 8.9 & 6.3 & 6.2 & 6 & 4 & 2.7 \\
\hline 65 & 6.7 & 9.8 & 5.9 & 9.3 & 6.1 & 2.8 & 7.6 & 7.8 & 5.8 & 7.8 & 4.4 & 4.9 & 7.4 & 7 & 5 & 7.1 & 6.7 & 9.8 & 5.9 & 9.3 & 6.1 & 2.8 \\
\hline 66 & 9.1 & 6.4 & 4.3 & 8 & 8.4 & 5.5 & 4.2 & 6.9 & 5.7 & 5 & 7.7 & 6.2 & 6.8 & 6 & 8.3 & 7.8 & 9.1 & 6.4 & 4.3 & 8 & 8.4 & 5.5 \\
\hline 67 & 7.8 & 9 & 3.5 & 7.7 & 5.6 & 5.3 & 3.6 & 4.6 & 8 & 6.3 & 6.4 & 4.2 & 7.3 & 6.7 & 6 & 6.4 & 7.8 & 9 & 3.5 & 7.7 & 5.6 & 5.3 \\
\hline 68 & 8.9 & 6.8 & 9.3 & 7.1 & 5.7 & 7.6 & 6.8 & 7.4 & 3.9 & 7.1 & 7.6 & 4.3 & 7.4 & 7.1 & 7 & 7.1 & 8.9 & 6.8 & 9.3 & 7.1 & 5.7 & 7.6 \\
\hline
\end{tabular}




\begin{tabular}{|c|c|c|c|c|c|c|c|c|c|c|c|c|c|c|c|c|c|c|c|c|c|c|}
\hline 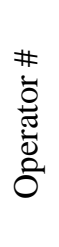 & $\underset{8}{\infty}$ & 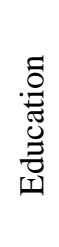 & 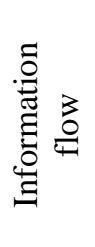 & 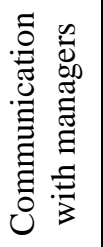 & 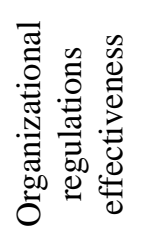 & 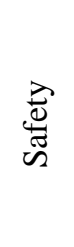 & 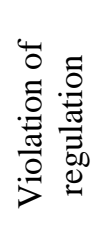 & 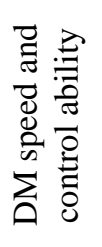 & 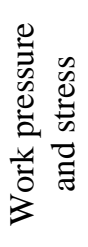 & 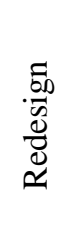 & 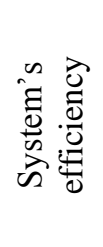 & 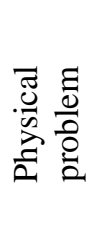 & 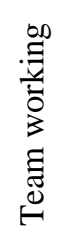 & 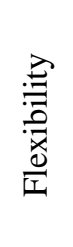 & 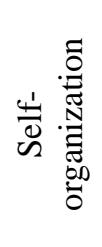 & 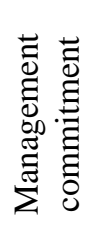 & 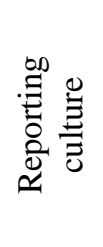 & 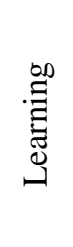 & 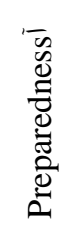 & 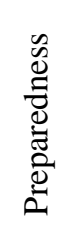 & 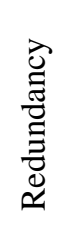 & 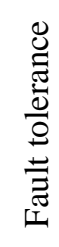 \\
\hline 69 & 9.4 & 9.8 & 4.8 & 6.4 & 5.7 & 6 & 6.1 & 8.3 & 7.2 & 4.1 & 3.8 & 4.9 & 7.1 & 6.4 & 7.3 & 8.7 & 9.4 & 9.8 & 4.8 & 6.4 & 5.7 & 6 \\
\hline 70 & 6.5 & 7.3 & 3.4 & 9.8 & 9.3 & 4.8 & 8.6 & 7.5 & 3.5 & 6.6 & 4 & 5.7 & 4.8 & 6.1 & 5.2 & 5.6 & 6.5 & 7.3 & 3.4 & 9.8 & 9.3 & 4.8 \\
\hline 71 & 7.6 & 8.1 & 6.6 & 9.3 & 5.3 & 7.1 & 6.8 & 7 & 4.9 & 4.2 & 2.9 & 6.2 & 4.9 & 4.2 & 7.1 & 7.9 & 7.6 & 8.1 & 6.6 & 9.3 & 5.3 & 7.1 \\
\hline 72 & 7 & 8.6 & 6.1 & 8.6 & 6.2 & 7.9 & 9 & 4.2 & 4.6 & 5.5 & 6.2 & 4.7 & 7.2 & 4.1 & 8.3 & 7.1 & 7 & 8.6 & 6.1 & 8.6 & 6.2 & 7.9 \\
\hline 73 & 7 & 8.5 & 6.3 & 9.5 & 8.2 & 5.3 & 8.8 & 4.3 & 7.6 & 5.9 & 4 & 7 & 5 & 4.5 & 7.7 & 8.9 & 7 & 8.5 & 6.3 & 9.5 & 8.2 & 5.3 \\
\hline 74 & 8.7 & 9.4 & 6.1 & 7 & 9.7 & 4.2 & 4.5 & 7.3 & 7.7 & 5.3 & 3.3 & 3.7 & 6.1 & 7.1 & 9.3 & 7.9 & 8.7 & 9.4 & 6.1 & 7 & 9.7 & 4.2 \\
\hline 75 & 7 & 6.8 & 9.4 & 5.7 & 8.1 & 2.6 & 9.3 & 3.8 & 7.2 & 7 & 3.4 & 4.7 & 6.5 & 5.9 & 8.3 & 6.2 & 7 & 6.8 & 9.4 & 5.7 & 8.1 & 2.6 \\
\hline 76 & 9.3 & 7.6 & 4.3 & 6 & 7.3 & 5.3 & 4.8 & 5.2 & 4.8 & 7 & 5.1 & 5.1 & 7.1 & 6.3 & 6.4 & 6.9 & 9.3 & 7.6 & 4.3 & 6 & 7.3 & 5.3 \\
\hline 77 & 9.3 & 7.5 & 3.8 & 9.8 & 8.8 & 4.3 & 7.7 & 5 & 4.7 & 4.2 & 4 & 3.7 & 6.3 & 7.9 & 7.4 & 9 & 9.3 & 7.5 & 3.8 & 9.8 & 8.8 & 4.3 \\
\hline 78 & 7.6 & 7.8 & 6.1 & 9.3 & 7.7 & 5.8 & 3.8 & 3.7 & 3.1 & 5 & 6.1 & 5.7 & 5.5 & 6.8 & 5.1 & 8.4 & 7.6 & 7.8 & 6.1 & 9.3 & 7.7 & 5.8 \\
\hline 79 & 8.9 & 7 & 5 & 9.5 & 5.3 & 9.7 & 3.5 & 5.7 & 7 & 6.2 & 6.9 & 5.7 & 6.6 & 5.2 & 9.5 & 9.1 & 8.9 & 7 & 5 & 9.5 & 5.3 & 9.7 \\
\hline 80 & 6.8 & 9.5 & 3.2 & 5.9 & 5.8 & 7.5 & 8.7 & 6.7 & 3.9 & 4.7 & 6 & 6.3 & 7 & 5 & 8.1 & 7.6 & 6.8 & 9.5 & 3.2 & 5.9 & 5.8 & 7.5 \\
\hline 81 & 7.2 & 8.8 & 9.6 & 9.1 & 5.3 & 9.2 & 5.4 & 7.5 & 6.2 & 5.6 & 6.7 & 5.2 & 5.9 & 7.3 & 6.4 & 7.3 & 7.2 & 8.8 & 9.6 & 9.1 & 5.3 & 9.2 \\
\hline 82 & 9.8 & 7.5 & 8.4 & 9.3 & 8.2 & 5.7 & 6.2 & 3.7 & 3.2 & 6.4 & 2.6 & 4 & 6.6 & 4.5 & 5.9 & 8.5 & 9.8 & 7.5 & 8.4 & 9.3 & 8.2 & 5.7 \\
\hline 83 & 7.9 & 8.8 & 4.6 & 7.9 & 4.6 & 9.5 & 9.1 & 7.7 & 6.4 & 5.1 & 5.3 & 5.7 & 7.6 & 7 & 7.7 & 9 & 7.9 & 8.8 & 4.6 & 7.9 & 4.6 & 9.5 \\
\hline 84 & 9.1 & 7.2 & 7.8 & 7.4 & 6.9 & 9.4 & 8.2 & 4.6 & 4.7 & 7 & 6.2 & 3.8 & 4.4 & 5.5 & 5.3 & 5.7 & 9.1 & 7.2 & 7.8 & 7.4 & 6.9 & 9.4 \\
\hline 85 & 7.2 & 6 & 6.8 & 5.5 & 8.5 & 8.7 & 4.2 & 4.5 & 3.4 & 6.4 & 6.3 & 5.8 & 5.5 & 6.2 & 6.6 & 9.8 & 7.2 & 6 & 6.8 & 5.5 & 8.5 & 8.7 \\
\hline 86 & 9.5 & 9.8 & 8.4 & 4.8 & 6 & 6.8 & 6.7 & 7.9 & 2.6 & 5.1 & 3.3 & 5.7 & 7.4 & 6.8 & 9.4 & 8.8 & 9.5 & 9.8 & 8.4 & 4.8 & 6 & 6.8 \\
\hline 87 & 6.9 & 7.6 & 4.7 & 8.5 & 5.3 & 5.6 & 4.8 & 5.1 & 3.8 & 5.6 & 6.1 & 3.9 & 5.8 & 6.9 & 9.4 & 8.9 & 6.9 & 7.6 & 4.7 & 8.5 & 5.3 & 5.6 \\
\hline 88 & 8.1 & 9.8 & 7.8 & 6.8 & 7.3 & 6.8 & 5.5 & 3.8 & 2.6 & 4.9 & 7.9 & 3.9 & 5.5 & 6.5 & 9.4 & 7.7 & 8.1 & 9.8 & 7.8 & 6.8 & 7.3 & 6.8 \\
\hline 89 & 8.9 & 7.3 & 7.3 & 9.4 & 7.4 & 2.1 & 5.8 & 5.7 & 7 & 6.9 & 7.2 & 5.3 & 6.8 & 7.1 & 8.5 & 7.7 & 8.9 & 7.3 & 7.3 & 9.4 & 7.4 & 2.1 \\
\hline 90 & 8.9 & 8.3 & 6.6 & 6.7 & 5.1 & 4.6 & 7.8 & 4.5 & 8.3 & 4.3 & 6.3 & 5.5 & 5.9 & 7.9 & 5.7 & 6.5 & 8.9 & 8.3 & 6.6 & 6.7 & 5.1 & 4.6 \\
\hline 91 & 6.9 & 8.1 & 3.2 & 8.4 & 7.5 & 10 & 3.3 & 5.6 & 6 & 6.2 & 3.3 & 5.8 & 6.1 & 7.3 & 9.3 & 9.3 & 6.9 & 8.1 & 3.2 & 8.4 & 7.5 & 10 \\
\hline
\end{tabular}




\begin{tabular}{|c|c|c|c|c|c|c|c|c|c|c|c|c|c|c|c|c|c|c|c|c|c|c|}
\hline $\begin{array}{l}\# \\
\overline{0} \\
\overline{0} \\
\tilde{0} \\
\tilde{0}\end{array}$ & $\underset{8}{\infty}$ & 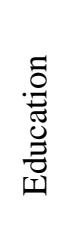 & 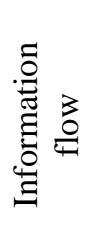 & 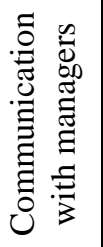 & 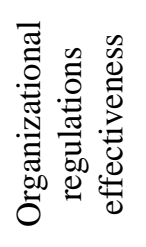 & 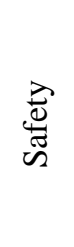 & 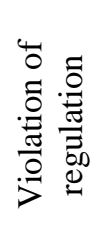 & 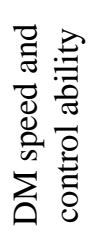 & 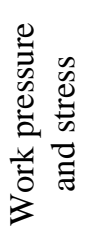 & 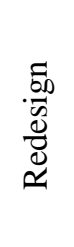 & 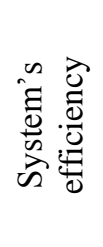 & 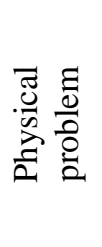 & 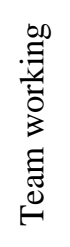 & 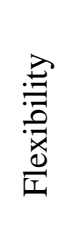 & 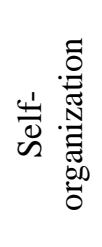 & 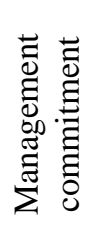 & 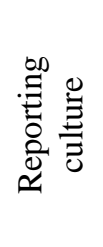 & 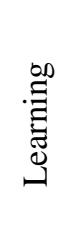 & 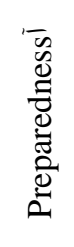 & 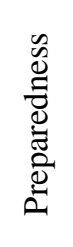 & 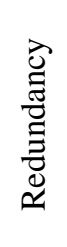 & 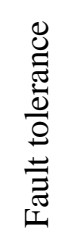 \\
\hline 92 & 7.4 & 9.5 & 8.9 & 8.3 & 5.8 & 8 & 4.2 & 3.8 & 3.8 & 6.6 & 3.8 & 3.7 & 6.7 & 4.4 & 9.2 & 5.6 & 7.4 & 9.5 & 8.9 & 8.3 & 5.8 & 8 \\
\hline 93 & 9.6 & 9 & 7.6 & 5.7 & 6.1 & 5.3 & 8.3 & 6.1 & 3.9 & 5.5 & 2.6 & 3.6 & 6.1 & 6 & 8.1 & 9.8 & 9.6 & 9 & 7.6 & 5.7 & 6.1 & 5.3 \\
\hline 94 & 9.4 & 7.7 & 7.4 & 9.8 & 8.4 & 9.3 & 7.7 & 4.6 & 4.1 & 7.7 & 2.8 & 4.1 & 7.6 & 6.6 & 8.9 & 8.6 & 9.4 & 7.7 & 7.4 & 9.8 & 8.4 & 9.3 \\
\hline 95 & 9.3 & 7.2 & 4.6 & 7 & 4.1 & 3.5 & 5.2 & 4.9 & 7.4 & 5 & 7.9 & 6.8 & 7 & 6.9 & 9.3 & 6 & 9.3 & 7.2 & 4.6 & 7 & 4.1 & 3.5 \\
\hline 96 & 7.8 & 9.7 & 6.7 & 6.3 & 8 & 2.6 & 5.6 & 8.3 & 8.1 & 7.5 & 3.1 & 6.5 & 4.5 & 5.3 & 5.8 & 6 & 7.8 & 9.7 & 6.7 & 6.3 & 8 & 2.6 \\
\hline 97 & 8.3 & 7.4 & 3.6 & 7.2 & 7.3 & 5.6 & 6.5 & 6.2 & 9 & 6.9 & 5.2 & 6.3 & 5.7 & 7.4 & 6 & 5.5 & 8.3 & 7.4 & 3.6 & 7.2 & 7.3 & 5.6 \\
\hline 98 & 8.6 & 8.7 & 6.6 & 6.9 & 9.3 & 3.5 & 5.7 & 4.9 & 8.1 & 7 & 7.4 & 4.7 & 5.6 & 4.9 & 5.2 & 7.4 & 8.6 & 8.7 & 6.6 & 6.9 & 9.3 & 3.5 \\
\hline 99 & 8.7 & 6.7 & 4.5 & 5 & 5.9 & 6.5 & 7.3 & 8.3 & 8.8 & 5.9 & 6.3 & 4.7 & 6.2 & 5 & 8.1 & 6.4 & 8.7 & 6.7 & 4.5 & 5 & 5.9 & 6.5 \\
\hline 100 & 9.4 & 8.6 & 9.1 & 7.5 & 4.9 & 1.5 & 9.2 & 7.8 & 4 & 5.6 & 7.8 & 6.8 & 5.2 & 6.8 & 5 & 8.8 & 9.4 & 8.6 & 9.1 & 7.5 & 4.9 & 1.5 \\
\hline 101 & 9.5 & 7.7 & 9 & 7.4 & 5.6 & 3.7 & 5.8 & 6 & 5.4 & 5.7 & 3.5 & 5.9 & 6.3 & 7.9 & 8.2 & 9.4 & 9.5 & 7.7 & 9 & 7.4 & 5.6 & 3.7 \\
\hline 102 & 8.9 & 8.7 & 5.5 & 6 & 4.1 & 9.9 & 9.1 & 6 & 3.2 & 5 & 4.6 & 3.8 & 7 & 7.8 & 7.9 & 5.9 & 8.9 & 8.7 & 5.5 & 6 & 4.1 & 9.9 \\
\hline 103 & 7.1 & 9.3 & 9 & 5.3 & 3.8 & 7.9 & 6.9 & 4.5 & 3.4 & 6.3 & 2.7 & 4.5 & 7.4 & 4.9 & 6.1 & 8.2 & 7.1 & 9.3 & 9 & 5.3 & 3.8 & 7.9 \\
\hline 104 & 10 & 8.7 & 5.5 & 9.9 & 7.5 & 9 & 3.5 & 4 & 5.5 & 5.9 & 2.9 & 4.9 & 5.7 & 5.1 & 8.6 & 8.8 & 10 & 8.7 & 5.5 & 9.9 & 7.5 & 9 \\
\hline 105 & 6.5 & 6.4 & 5.4 & 9.9 & 7.4 & 8.2 & 3.5 & 7.3 & 3.7 & 6.3 & 4.6 & 5.7 & 7 & 5 & 5.5 & 8.2 & 6.5 & 6.4 & 5.4 & 9.9 & 7.4 & 8.2 \\
\hline 106 & 9.4 & 9.9 & 5.8 & 8.9 & 4.2 & 4.5 & 4.6 & 7.5 & 3.1 & 6.4 & 7.8 & 6.6 & 5.3 & 5.6 & 9.3 & 9.6 & 9.4 & 9.9 & 5.8 & 8.9 & 4.2 & 4.5 \\
\hline 107 & 9.4 & 8.8 & 7.3 & 8.6 & 9.3 & 10 & 4.5 & 5 & 7.5 & 5.2 & 2.5 & 5.2 & 6.8 & 4.8 & 9 & 6.4 & 9.4 & 8.8 & 7.3 & 8.6 & 9.3 & 10 \\
\hline 108 & 9.7 & 9.5 & 6.4 & 5.6 & 4.6 & 9.2 & 5.3 & 5.1 & 3.5 & 4 & 5.4 & 7 & 4.8 & 5.8 & 6 & 8.9 & 9.7 & 9.5 & 6.4 & 5.6 & 4.6 & 9.2 \\
\hline 109 & 9.1 & 9.4 & 8.9 & 5.6 & 9.3 & 9.7 & 3.7 & 6.8 & 8.1 & 6.3 & 3.2 & 5.8 & 7.7 & 5.6 & 8 & 9.1 & 9.1 & 9.4 & 8.9 & 5.6 & 9.3 & 9.7 \\
\hline 110 & 9.4 & 9.6 & 8.9 & 9.1 & 7.4 & 9.1 & 5.4 & 5.1 & 7.3 & 4.1 & 7.4 & 4.3 & 5.6 & 7.3 & 7 & 5.9 & 9.4 & 9.6 & 8.9 & 9.1 & 7.4 & 9.1 \\
\hline 111 & 8.9 & 6.6 & 5.1 & 5 & 6.3 & 9.7 & 7 & 4.5 & 2.6 & 5.7 & 3.8 & 5.6 & 7.5 & 4.5 & 6.1 & 9.8 & 8.9 & 6.6 & 5.1 & 5 & 6.3 & 9.7 \\
\hline 112 & 8.2 & 9.5 & 4.3 & 9.1 & 5.8 & 4.5 & 4.2 & 7 & 2.6 & 5.6 & 3.8 & 4.7 & 7.6 & 4.4 & 6 & 8.2 & 8.2 & 9.5 & 4.3 & 9.1 & 5.8 & 4.5 \\
\hline 113 & 6.9 & 8.9 & 9.9 & 5.8 & 9.1 & 5.5 & 9 & 6.8 & 3.4 & 5.5 & 7.8 & 3.6 & 6.8 & 6 & 6.7 & 9.9 & 6.9 & 8.9 & 9.9 & 5.8 & 9.1 & 5.5 \\
\hline 114 & 8.9 & 6.3 & 6.5 & 5.7 & 9.2 & 2 & 4.4 & 4.3 & 2.5 & 7.2 & 6.9 & 5.1 & 6.6 & 5.3 & 5.5 & 6.6 & 8.9 & 6.3 & 6.5 & 5.7 & 9.2 & 2 \\
\hline
\end{tabular}




\begin{tabular}{|c|c|c|c|c|c|c|c|c|c|c|c|c|c|c|c|c|c|c|c|c|c|c|}
\hline $\begin{array}{l}\# \\
\overline{0} \\
\overline{0} \\
\tilde{0} \\
\tilde{0}\end{array}$ & $\underset{8}{\infty}$ & 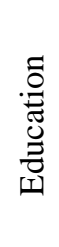 & 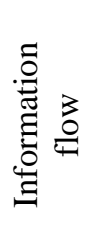 & 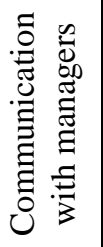 & 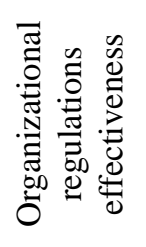 & 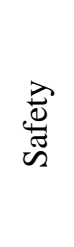 & 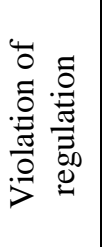 & 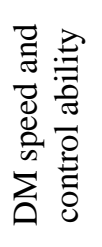 & 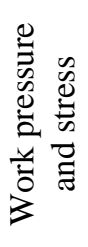 & 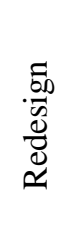 & 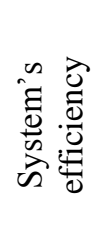 & 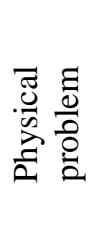 & 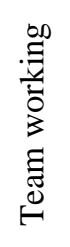 & 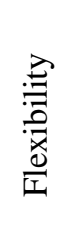 & 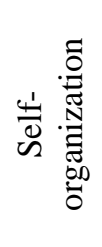 & 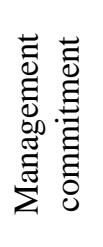 & 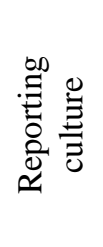 & 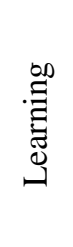 & 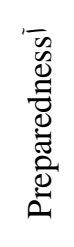 & 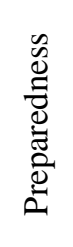 & 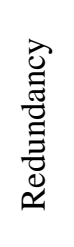 & 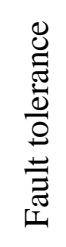 \\
\hline 115 & 9.1 & 7.7 & 6.4 & 9.2 & 7 & 6.7 & 6.7 & 8 & 7.1 & 6.8 & 7.9 & 5.7 & 7.4 & 7.8 & 9.1 & 9.5 & 9.1 & 7.7 & 6.4 & 9.2 & 7 & 6.7 \\
\hline 116 & 7.9 & 8.5 & 3.8 & 6.8 & 6.6 & 9 & 4.6 & 8.3 & 4.9 & 5.6 & 2.4 & 4.7 & 5.2 & 5 & 8.9 & 6.4 & 7.9 & 8.5 & 3.8 & 6.8 & 6.6 & 9 \\
\hline 117 & 7 & 9.8 & 4 & 6 & 7.3 & 9.7 & 8 & 7.3 & 5.5 & 7.3 & 3 & 4.5 & 5.7 & 6.5 & 8.5 & 9.5 & 7 & 9.8 & 4 & 6 & 7.3 & 9.7 \\
\hline 118 & 8.6 & 9.7 & 8.8 & 5.8 & 8.9 & 9.8 & 7.5 & 4.2 & 4.7 & 6.8 & 8 & 3.9 & 6.5 & 4.9 & 9.4 & 8.1 & 8.6 & 9.7 & 8.8 & 5.8 & 8.9 & 9.8 \\
\hline 119 & 6.9 & 6.5 & 4.2 & 8.5 & 4.1 & 2.7 & 5.6 & 7.5 & 5.6 & 6.8 & 4.4 & 4.2 & 6.6 & 4.6 & 8.8 & 9.6 & 6.9 & 6.5 & 4.2 & 8.5 & 4.1 & 2.7 \\
\hline 120 & 6.6 & 9.2 & 8.2 & 8.4 & 5.5 & 5.2 & 7.2 & 8.3 & 5.1 & 7.1 & 5.2 & 5.9 & 6.3 & 6.7 & 8.6 & 7.1 & 6.6 & 9.2 & 8.2 & 8.4 & 5.5 & 5.2 \\
\hline 121 & 7.4 & 9.5 & 3.9 & 7.4 & 9.9 & 8.8 & 9.1 & 7.7 & 4.6 & 7.1 & 6.7 & 5.9 & 6.6 & 6.3 & 9 & 8.3 & 7.4 & 9.5 & 3.9 & 7.4 & 9.9 & 8.8 \\
\hline 122 & 8.6 & 6.2 & 5.6 & 9.1 & 5.6 & 8.1 & 4.9 & 3.9 & 6.6 & 5.5 & 5.5 & 5.4 & 5.4 & 7.2 & 6.2 & 8.2 & 8.6 & 6.2 & 5.6 & 9.1 & 5.6 & 8.1 \\
\hline 123 & 8.4 & 8.4 & 9.3 & 6.7 & 9.5 & 6.7 & 7.5 & 6.8 & 8.4 & 5.6 & 4.8 & 6.7 & 6.5 & 7.3 & 5.7 & 9.9 & 8.4 & 8.4 & 9.3 & 6.7 & 9.5 & 6.7 \\
\hline 124 & 6.9 & 8.4 & 3.5 & 9.2 & 5.6 & 5.2 & 5.2 & 6.4 & 6.8 & 4.3 & 8.2 & 4.6 & 7 & 5 & 5 & 5.8 & 6.9 & 8.4 & 3.5 & 9.2 & 5.6 & 5.2 \\
\hline 125 & 7.6 & 8.4 & 9.7 & 5.9 & 10 & 8.4 & 6.9 & 5.5 & 6 & 7.6 & 7.7 & 4.9 & 6.4 & 4.8 & 5.5 & 5.8 & 7.6 & 8.4 & 9.7 & 5.9 & 10 & 8.4 \\
\hline 126 & 6.6 & 6.4 & 3.6 & 6.1 & 7.4 & 4 & 6.1 & 5.9 & 8.8 & 7.6 & 6.5 & 4.7 & 7.4 & 5.6 & 7 & 8 & 6.6 & 6.4 & 3.6 & 6.1 & 7.4 & 4 \\
\hline 127 & 7.8 & 7.8 & 8 & 9.8 & 4.2 & 6.4 & 8.6 & 6.5 & 2.7 & 3.8 & 5.1 & 6.4 & 7.6 & 4.6 & 7.3 & 8.6 & 7.8 & 7.8 & 8 & 9.8 & 4.2 & 6.4 \\
\hline 128 & 7.4 & 7 & 9.2 & 7.6 & 9.7 & 8 & 6.9 & 6.6 & 5.4 & 7.7 & 7.1 & 6.5 & 4.6 & 6.1 & 5.8 & 9.6 & 7.4 & 7 & 9.2 & 7.6 & 9.7 & 8 \\
\hline 129 & 6.9 & 8.9 & 4.3 & 6.2 & 4.5 & 1.6 & 3.6 & 4.2 & 6.3 & 7.3 & 5.5 & 6.8 & 5.5 & 7.4 & 8.9 & 7.9 & 6.9 & 8.9 & 4.3 & 6.2 & 4.5 & 1.6 \\
\hline 130 & 8.2 & 9.1 & 3.3 & 9.8 & 7.1 & 3.3 & 8 & 5.3 & 6.6 & 4.4 & 7.7 & 3.9 & 6.7 & 7.3 & 7.3 & 7.6 & 8.2 & 9.1 & 3.3 & 9.8 & 7.1 & 3.3 \\
\hline 131 & 8.4 & 7.5 & 5.4 & 5.9 & 5.8 & 5.3 & 3.8 & 4.2 & 8.7 & 5.5 & 5.7 & 6.6 & 7.7 & 6.8 & 6.7 & 7.8 & 8.4 & 7.5 & 5.4 & 5.9 & 5.8 & 5.3 \\
\hline 132 & 8.4 & 7.9 & 4.8 & 5.6 & 6.9 & 8.8 & 5.6 & 6.9 & 4.2 & 4.4 & 6.9 & 5.7 & 6.8 & 4.9 & 6.7 & 8.1 & 8.4 & 7.9 & 4.8 & 5.6 & 6.9 & 8.8 \\
\hline 133 & 8.7 & 6.2 & 9.2 & 9.3 & 8.4 & 6.3 & 5.9 & 7.5 & 3.2 & 6.5 & 5.6 & 4.9 & 7.5 & 7.4 & 6.2 & 6.2 & 8.7 & 6.2 & 9.2 & 9.3 & 8.4 & 6.3 \\
\hline 134 & 8.8 & 8.3 & 7.2 & 7.4 & 9.4 & 7.7 & 8.1 & 6.8 & 5.2 & 6.5 & 5.6 & 5.6 & 6.4 & 7 & 7.8 & 8.3 & 8.8 & 8.3 & 7.2 & 7.4 & 9.4 & 7.7 \\
\hline 135 & 9.5 & 6.4 & 9.9 & 7.6 & 10 & 5.9 & 3.7 & 7.6 & 8.2 & 4 & 2.8 & 6.9 & 5.8 & 4.6 & 5.5 & 7 & 9.5 & 6.4 & 9.9 & 7.6 & 10 & 5.9 \\
\hline 136 & 9 & 8.9 & 5.5 & 7.2 & 7.5 & 3 & 7.2 & 6.2 & 7 & 4.7 & 4.3 & 4.5 & 5.1 & 6 & 8.8 & 6.9 & 9 & 8.9 & 5.5 & 7.2 & 7.5 & 3 \\
\hline 137 & 9.9 & 8.8 & 5.3 & 9.8 & 4.8 & 9.4 & 5.1 & 7.1 & 8 & 7.4 & 6.4 & 6.1 & 6.4 & 4.9 & 9.3 & 6.9 & 9.9 & 8.8 & 5.3 & 9.8 & 4.8 & 9.4 \\
\hline
\end{tabular}




\begin{tabular}{|c|c|c|c|c|c|c|c|c|c|c|c|c|c|c|c|c|c|c|c|c|c|c|}
\hline 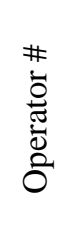 & $\underset{\mathbb{Z}}{\mathbb{\infty}}$ & 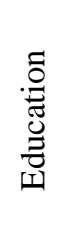 & 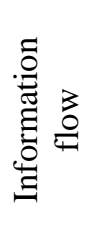 & 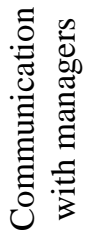 & 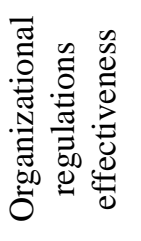 & 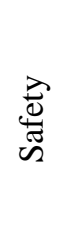 & 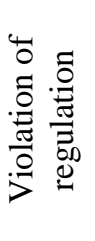 & 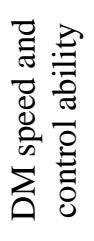 & 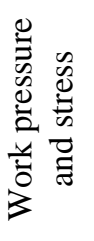 & 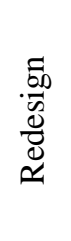 & 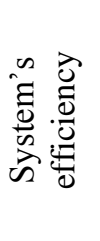 & 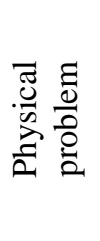 & 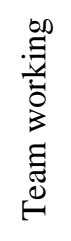 & 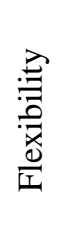 & 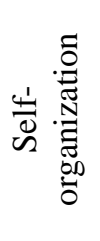 & 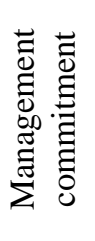 & 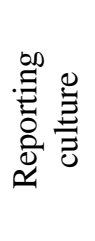 & . & 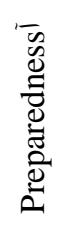 & 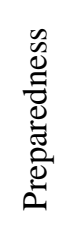 & 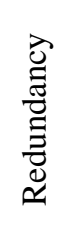 & 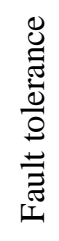 \\
\hline 138 & 9.9 & 7.2 & 8.4 & 8.8 & 4.3 & 7.7 & 4.7 & 7.8 & 6.3 & 5 & 3.9 & 6.6 & 5.9 & 5.6 & 5.3 & 5.9 & 9.9 & 7.2 & 8.4 & 8.8 & 4.3 & 7.7 \\
\hline 139 & 9.8 & 8.3 & 3.6 & 6.5 & 4.6 & 3.4 & 4.3 & 4.5 & 6.4 & 5.6 & 3.8 & 5 & 4.7 & 6.8 & 6.6 & 7.2 & 9.8 & 8.3 & 3.6 & 6.5 & 4.6 & 3.4 \\
\hline 140 & 6.8 & 7.8 & 6 & 5.8 & 6.3 & 4.3 & 8.2 & 4.7 & 5.1 & 6.5 & 4.3 & 6.3 & 4.6 & 4.4 & 6.7 & 8.4 & 6.8 & 7.8 & 6 & 5.8 & 6.3 & 4.3 \\
\hline 141 & 9.6 & 9.6 & 7.1 & 5.5 & 4.7 & 3.7 & 6.7 & 5 & 7.8 & 6.9 & 3.9 & 4.7 & 7.8 & 6.2 & 7.3 & 6.4 & 9.6 & 9.6 & 7.1 & 5.5 & 4.7 & 3.7 \\
\hline 142 & 7.2 & 7.3 & 5.7 & 5.5 & 7.3 & 8.8 & 9.3 & 6.3 & 2.7 & 5.3 & 6.9 & 3.6 & 5.9 & 7.8 & 5.3 & 7.3 & 7.2 & 7.3 & 5.7 & 5.5 & 7.3 & 8.8 \\
\hline 143 & 6.8 & 7.3 & 3.5 & 5.8 & 3.9 & 9 & 8.3 & 6.2 & 8.6 & 7.9 & 4.6 & 5.4 & 6.4 & 4.1 & 6.2 & 7.1 & 6.8 & 7.3 & 3.5 & 5.8 & 3.9 & 9 \\
\hline 144 & 7.1 & 8.9 & 8.6 & 8 & 5.1 & 6.8 & 7.9 & 5.5 & 4.7 & 5 & 3.7 & 6.4 & 6 & 5.5 & 7.2 & 8.5 & 7.1 & 8.9 & 8.6 & 8 & 5.1 & 6.8 \\
\hline 145 & 7 & 9.3 & 5.8 & 4.8 & 5.9 & 5.9 & 8.5 & 8.2 & 6.1 & 5 & 4.9 & 5.9 & 7.2 & 5.4 & 8.4 & 6.1 & 7 & 9.3 & 5.8 & 4.8 & 5.9 & 5.9 \\
\hline 146 & 8.8 & 8.8 & 8.3 & 8.9 & 3.8 & 7.3 & 9.2 & 8 & 8.1 & 6.3 & 7.1 & 5.1 & 4.7 & 6.5 & 6.1 & 9.3 & 8.8 & 8.8 & 8.3 & 8.9 & 3.8 & 7.3 \\
\hline 147 & 7.3 & 6.2 & 7 & 9.4 & 6.4 & 4.6 & 8.2 & 6.5 & 5.7 & 4.3 & 6.2 & 6.4 & 4.8 & 4.4 & 6.6 & 7.7 & 7.3 & 6.2 & 7 & 9.4 & 6.4 & 4.6 \\
\hline 148 & 6.8 & 8.9 & 9 & 7.3 & 8.8 & 5.2 & 8.8 & 6.1 & 7.2 & 6.7 & 2.8 & 6.1 & 6.4 & 6 & 6.5 & 5.5 & 6.8 & 8.9 & 9 & 7.3 & 8.8 & 5.2 \\
\hline 149 & 8.7 & 7.3 & 5.5 & 5.1 & 4.5 & 6.2 & 3.7 & 4 & 7.9 & 5.9 & 4.9 & 5.9 & 6.4 & 5.9 & 9 & 5.8 & 8.7 & 7.3 & 5.5 & 5.1 & 4.5 & 6.2 \\
\hline 150 & 9.5 & 7.6 & 6.6 & 4.3 & 2.2 & 7.1 & 5.6 & 5.2 & 7.5 & 2.4 & 5.4 & 5.6 & 4.4 & 6.9 & 6.4 & 6.5 & 9.5 & 7.6 & 6.6 & 4.3 & 2.2 & 7.1 \\
\hline
\end{tabular}

